2019-10-15

Using microlites to gain insights into ascent conditions of differing styles of volcanism at Soufriere Hills Volcano

\author{
Murch, AP
}

http://hdl.handle.net/10026.1/14766

\begin{abstract}
10.1016/j.jvolgeores.2019.07.022
Journal of Volcanology and Geothermal Research

Elsevier
\end{abstract}

All content in PEARL is protected by copyright law. Author manuscripts are made available in accordance with publisher policies. Please cite only the published version using the details provided on the item record or document. In the absence of an open licence (e.g. Creative Commons), permissions for further reuse of content should be sought from the publisher or author. 


\section{Journal Pre-proof}

Using microlites to gain insights into ascent conditions of differing styles of volcanism at Soufrière Hills Volcano

Arran P. Murch, Paul D. Cole

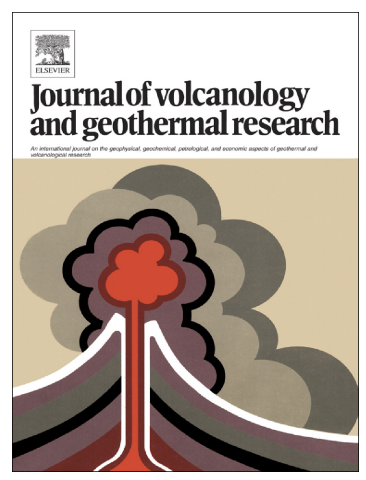

PII:

S0377-0273(18)30374-3

DOI: $\quad$ https://doi.org/10.1016/j.jvolgeores.2019.07.022

Reference: $\quad$ VOLGEO 6655

To appear in: Journal of Volcanology and Geothermal Research

Received date: $\quad 31$ August 2018

Revised date: $\quad 23$ July 2019

Accepted date: $\quad 27$ July 2019

Please cite this article as: A.P. Murch and P.D. Cole, Using microlites to gain insights into ascent conditions of differing styles of volcanism at Soufrière Hills Volcano, Journal of Volcanology and Geothermal Research(2019), https:/doi.org/10.1016/ j.jvolgeores.2019.07.022

This is a PDF file of an article that has undergone enhancements after acceptance, such as the addition of a cover page and metadata, and formatting for readability, but it is not yet the definitive version of record. This version will undergo additional copyediting, typesetting and review before it is published in its final form, but we are providing this version to give early visibility of the article. Please note that, during the production process, errors may be discovered which could affect the content, and all legal disclaimers that apply to the journal pertain.

(C) 2019 Published by Elsevier. 


\title{
Using microlites to gain insights into ascent conditions of differing styles of volcanism at Soufrière Hills Volcano
}

\author{
Arran P. Murch ${ }^{\mathrm{a}, \mathrm{b}, *}$ and Paul D. Cole ${ }^{\mathrm{a}}$ \\ a School of Geography, Earth and Environmental Science, University of Plymouth, Plymouth, UK \\ ${ }^{\mathrm{b}}$ Geology Department, University of Otago, PO Box 56, Dunedin, 9054, New Zealand
}

* corresponding author Email Address: Arranmurch@googlemail.com (Arran P. Murch)

\begin{abstract}
Microlite textural characteristics are analyzed in the products of Vulcanian explosions, ash venting occurring synchronously with lava effusion (syn-extrusive ash venting), a precursory explosion, and lava dome effusion associated with Phases 3 , and 5 of the current Soufrière Hills Volcano (SHV) eruption. 2D microlite population statistics and crystal size distributions are used to infer decompression pathways for each style of volcanism. In addition, magma ascent rates for each eruptive style were calculated using microlite number density (Toramaru et al. 2008).

Strong differences between pyroclastic and effusive microlites are observed in 2D population statistics and crystal size distributions, indicating higher amounts of smaller microlites in the lava dome compared with pyroclastic products. Crystal size distributions show that the lava dome and Vulcanian explosion samples have similar amounts of large microlites (>0.0084 to $0.012 \mathrm{~mm}$ ). However, syn-extrusive ash venting samples have comparatively higher amounts of large microlites. The similarity between lava dome and Vulcanian explosions at larger microlite sizes suggests comparable crystallization conditions in the deeper conduit system ( $>2 \mathrm{~km}$ depth). The contrast in eruption style despite similarity at depth suggests a shallow control to eruption processes at SHV. The higher amounts of large microlites in syn-extrusive ash venting compared to the lava dome indicates two distinct decompression pathways within a single conduit, inferred to result from differences in ascent rate. Sluggish conduit margin ascent leading to lower decompression rates is
\end{abstract}


inferred to produce the increased degree of crystal growth observed in syn-extrusive ash venting compared with the lava dome.

Calculated magma ascent rates for Vulcanian explosions and syn-extrusive ash venting have similar ranges, while lava effusion is up to a factor of 10 faster. Differences in magma ascent rate are inferred to result from variations in the depth at which ascent rate is calculated for each eruptive style. Ascent rate is calculated at microlite nucleation depth using the method of Toramaru et al. (2008). However, the average microlite nucleation depth will vary because of differences in microlite nucleation rate during ascent. More small microlites in the lava dome suggest higher nucleation rates in the shallow conduit, producing an on average shallower magma ascent rate ( $<1 \mathrm{~km}$ depth). Rapid decompression during pyroclastic eruptions restricts shallow crystallization, suggesting the microlite population is on average recording the deeper conduit system (>2km depth).

Keywords: Microlites; Crystal Size Distribution; Soufrière Hills Volcano; explosive-effusive eruption; Magma ascent

Highlights:

- Examined microlite textures from a range of juvenile pyroclastic and effusive samples

- Synchronous dome effusion and ash venting display contrasting microlite textures

- Differences in microlite crystallization depth and rate record magma conditions at different depths depending on eruption style

- Differences in ascent rate across the magma column produce lower decompression rates in conduit margin magma observed as ash venting

- Ascent rate calculated using microlite population records deeper conditions for pyroclastic activity due to restricted crystallization as a result of rapid decompression during eruption

\section{Introduction}

Variations in decompression pathway during shallow ascent play a large role in dictating the style and behavior of volcanism in magma of similar compositions (Sparks 1978; Cashman 2004; Mueller et al. 2008; Toramaru et al. 2008; Kendrick et al. 2016). Water exsolution due to decompression plays a pivotal role in this, impacting magma rheological, physical, and chemical properties through crystallization and vesiculation (Giordano et al. 2005; van Otterloo et al. 2015). Knowledge of decompression can therefore be used to understand the processes leading to, and generating, different styles of volcanism. 
Water exsolution in the shallow conduit drives crystallization by increasing the stability of anhydrous crystals whilst also raising the melts liquidus temperature resulting in undercooling, defined as the difference between a magma's liquidus and its actual temperature (Swanson 1977). Crystallization processes are strongly controlled by the degree of undercooling. Crystals formed during shallow ascent therefore preserve a record of the magma's decompression conditions above the water exsolution depth, and can be used as a proxy to assess pre-eruption shallow conduit conditions (Geschwind and Rutherford 1995; Hammer et al. 2000; Toramaru et al. 2008; Preece et al. 2013). These crystals, termed microlites, are defined as having cross sectional areas of less than $100 \mu \mathrm{m}^{2}$ (Clarke et al. 2007).

In this paper we use microlites to shed light on the pre-eruption conduit conditions and magma decompression processes for a range of styles of volcanism produced during the most recent eruptive period (2005-2010) at Soufrière Hills Volcano (SHV). Tephra generated during several types of activity, including Vulcanian explosions, syn-extrusive ash venting, and a pre-cursory explosion, as well as lava from effusive activity were studied. We examine the pre-eruption conduit processes and conditions for each eruption type. Information on the difference in pre-eruption conduit conditions for various styles of volcanism could be used to inform models on future eruptions at SHV and similar eruptions at other volcanoes. Of great importance for hazard management are understanding the processes that drive the transition between explosive and effusive activity especially during Montserrat style eruptions where rapid regular changes in eruptive style are observed.

\section{Soufrière Hills Volcano eruptive setting}

Soufrière Hills Volcano is the youngest of four volcanic centers located on the island of Montserrat in the northern part of the Lesser Antilles Island Arc (Fig. 1). Volcanism has occurred at Montserrat since approximately $2.17 \mathrm{Ma}$ forming the Silver Hills ( 2.17-1.03 Ma), Centre Hills ( 1.14-0.380 Ma), and Soufrière - South Soufrière Hills ( 0.45 Ma -present) centers (Hatter et al. 2018) (Fig. 1). Soufrière Hills Volcano is composed of a number of overlapping lava domes that show a narrow andesitic compositional range (58-64 wt\% $\mathrm{SiO}_{2}$ ) (Sparks and Young 2002).

The current eruption at SHV began on 18 July 1995 (Sparks and Young 2002; Wadge et al. 2014) and occurred in five phases (Wadge et al. 2014). It has generated $>100$ Vulcanian explosions of variable magnitude (Bonadonna et al. 2002; Druitt et al. 2002; Clarke et al. 2007; Cole et al. 2014b), and periods of ash venting occurring both synchronously with dome extrusion and during precursory 
activity (Bonadonna et al. 2002; Norton et al. 2002; Cole et al. 2014a). Here we examine tephra generated during a precursory explosion, two syn-eruptive ash venting events and two Vulcanian explosions related to Phases 3 and 5 in 2005, 2006, 2009 and 2010 (Table. 1).

Phase 3 of the recent SHV eruption is inferred to have begun on $1^{\text {st }}$ Aug 2005 with the effusion of fresh lava (Loughlin et al. 2010; Wadge et al. 2014). During this phase there was intermittent lava effusion the average rate of which increased rapidly from its onset (Ryan et al. 2010; Wadge et al. 2014). Lava effusion slowed through 2007 with the end of phase 3 considered to be on $20^{\text {th }} \mathrm{Apr} 2007$ as the dome growth rate became undetectable (Ryan et al. 2010; Wadge et al. 2014).

Phase 5 began on $5^{\text {th }}$ Oct 2009 with a series of ash venting events over three days, this was followed by rapid lava dome extrusion in three periods over the next four months (Stinton et al. 2014a; Wadge et al. 2014). Several periods of cyclicity were noted during this phase with ash venting occurring every 3-14 hrs (Wadge et al. 2014). Five Vulcanian explosions occurred towards the end of phase 5 which ended with a partial dome collapse on $11^{\text {th }}$ Feb 2010 (Stinton et al. 2014b; Wadge et al. 2014).

\section{Sampling and methods}

Fallout deposits from two Vulcanian explosions, two ash venting events and a precursory explosion that occurred prior to the onset of lava effusion in phase 3 were sampled from a range of locations on Montserrat (Table. 1; Fig. 1). Componentry was conducted on 0 or $1 \phi(1$ or $0.5 \mathrm{~mm}$ ) ash with grains counted into vesicular and crystalline groups. Thin sections were made from larger than $0 \phi$ ash to characterize petrology. In addition, juvenile lava blocks were collected from a block and ash flow deposit at Trants to characterize the lava dome (Table. 1).

A random selection of juvenile grains from the 0 and $1 \phi$ size range of each sample were mounted as polished grain mounts and carbon coated. Back-scattered electron (BSE) images were taken on a JEOL 6610 LVSEM scanning electron microscope (SEM) at the University of Plymouth using an accelerating voltage of $15 \mathrm{keV}$ and a working distance of $10 \mathrm{~mm}$ at $800 \times$ magnification. Images of the particle groundmass were acquired avoiding phenocrysts. Groundmass crystals and vesicles were manually outlined using a vector drawing package. The processed images were exported to ImageJ $(1.47 \mathrm{t})$ and measurements of field of view area along with individual crystal area and dimensions (using fit ellipse tool), and number of crystals were conducted for both plagioclase and other microlites. 
The kinetics of decompression induced plagioclase microlite growth and nucleation are the best understood compared with other common crystal systems found in the SHV magma (i.e. pyroxene, amphibole, Fe-Ti oxides) and thus give the most meaningful results for conduit conditions (e.g. Hammer et al. 1999, 2000; Couch et al. 2003b; Clarke et al. 2007; Toramaru et al. 2008; Preece et al. 2013). Using the data collected from ImageJ analysis, plagioclase area fraction ( $\phi=$ total area of plagioclase crystals/total area of solid groundmass), mean plagioclase microlite aspect ratio, and plagioclase area number densities $\mathrm{N}_{\mathrm{a}}$ (number of crystals per $\mathrm{mm}^{2}$ ) were calculated. The characteristic plagioclase crystal size, $S_{n}(\mu \mathrm{m})$ and volumetric plagioclase number density $N_{v}$ (number of crystals $/ \mathrm{mm}^{3}$ ) were also calculated using Eq. 1 and 2 respectively (Cashman 1992).

$S_{n}=\left(\frac{\phi}{N_{a}}\right)^{0.5}$

$N_{v}=\frac{N_{a}}{S_{n}}$

When calculating $S_{n}$ and mean aspect ratio, only those crystals not cut by the image edge were considered.

Crystal size distributions (CSD) were calculated for images in which more than 200 crystals were outlined. Using CSDslice (Morgan and Jerram 2006) the average three dimensional habits (S: short, I: intermediate, and L: long) of the crystal populations were calculated for each image. CSDs were then calculated using CSDcorrections (version 1.4.0.2) (Higgins 2000). Rock fabric was set to massive, crystal shape values were input from CSDslice, and crystal roundness in all samples was estimated at 0.1 (on a scale where 0 is rectangular, and 1 an ellipsoid). The analyzed areas were corrected for vesicles. Five bins were set per decade meaning each bin is 1.6 times the size of the next smallest one. Any bins that contained less than five crystals were removed as they were considered imprecise (Higgins 2000).

\subsection{Calculating ascent rate}

Magma ascent rate has been calculated using the MND (microlite number density) water exsolution rate meter (Toramaru et al. 2008), The MND water exsolution rate meter calculates a magma ascent rate at the microlite nucleation depth.

Using the equations of Toramaru et al. (2008) for decompression rate $\left(d \mathrm{P}_{\mathrm{w}} / d z ;\right.$ Eq. 3) and ascent rate $\left(V_{n}\right.$; Eq. 6) we estimated magmatic ascent rates.

$\left|\frac{d P_{w}}{d z}\right|=\frac{c}{b}\left(\frac{N}{a}\right)^{\frac{2}{3}}$ 
Where $b$ is a constant ( 40 for plagioclase), $c$ is defined by

$c=11.2 \times 10^{6} \times C_{W}$

and a can be calculated using

$a=3 \times 10^{15 \pm 1+0.345 \Delta C_{S i}-0.65 C_{W}}$

Where $C_{w}$ and $C_{s i}$ are the water content and the groundmass silica content at the point of microlite nucleation respectively, and $\mathrm{N}$ is the microlite number volume calculated using Eq. 2 from (Cashman 1992). From the decompression rate magmatic ascent rate at the microlite nucleation depth can be calculated:

$V_{n}=\frac{1}{\rho g}\left|\frac{d P_{w}}{d z}\right|$

Where $\rho$ is the density of the vesiculated magma at the microlite nucleation depth and $g$ is acceleration due to gravity. It should be noted that for the calculation of a, both $C_{w}$ and $C_{s i}$ are part of an index and therefore small differences in each can lead to large variations in the calculated decompression rate. Errors of $5 \%$ in $\mathrm{C}_{\mathrm{si}}$ can result in differences of up to $500 \%$ in the calculated magmatic ascent rates.

Density was calculated using porosity measured from ImageJ analysis averaged across samples from the same eruptions (assuming a magma density of $2600 \mathrm{~kg} \mathrm{~m}^{-3}$ ).

\section{Results}

\subsection{Componentry}

For tephra samples two juvenile component groups were defined as vesicular, and crystalline particles based on visual differences in particle surface colour and texture, vesicularity, and morphology.

Vesicular particleswere generally light grey in colour, although some appeared orangey or darker grey. These particles generally had angular morphologies and were semi- to moderately-vesicular. Vesicular particles contained euhedral phenocrysts (crystals $>100 \mu \mathrm{m}$ in length), dominantly of plagioclase (60\%) with more minor proportions of hornblende (15\%), pyroxene (10\%), and Fe-Ti oxides (5\%). Phenocrysts typically comprised approximately $40 \%$ by area of vesicular particles. Crystalline particles were typically dark grey in colour with crystalline surfaces, although some were light grey. Crystalline particles were moderately- to non-vesicular and typically appeared blocky or 
angular. They also showed similar phenocryst populations to those observed in vesicular particles however, phenocrysts comprised up to $\sim 70 \%$ by area of the grain. Cristobalite was commonly observed infilling vesicles of crystalline particles.

The proportion of vesicular to crystalline particles varied between explosion samples (Fig. 1; Table. 1). The precursory explosion had the lowest proportion of vesicular particles at $30 \%$. The two Vulcanian explosion events and the 04/01/10 ash venting event had similar componentry compositions with 67 to $78 \%$ vesicular particles, while the 15/10/06 ash venting event had $96 \%$ vesicular particles.

Samples of the juvenile SHV lava dome were dark grey in colour, appearing weakly-vesicular. Lava samples show similar phenocryst populations to those observed in vesicular particles with phenocrysts also comprised approximately $40 \%$ area of the groundmass.

\subsection{Qualitative groundmass textures}

Microlite analysis was conducted on juvenile lava samples and vesicular grains from each explosive event. Crystalline grains were excluded due to their very high crystallinity and low vesicularity potentially indicating recrystallization, implying that their microlite populations might not be not reflective of primary ascent conditions.

Qualitative examination of BSE images shows that in all samples the groundmass microlite assemblage was composed dominantly of plagioclase (50-80\%), with minor amounts of pyroxene, amphibole and oxides the proportions of which varied between and within samples (Fig. 2).

The morphology of plagioclase, pyroxene, amphibole, and oxide microlites varied between the different styles of volcanism examined here (Table. 1). Tabular microlites were observed in samples of every eruption style, however the lava dome samples showed only tabular microlites (Fig. 2). In contrast, explosively produced tephra, also showed acicular, hopper, and swallow tail microlite morphologies (Fig. 2). Samples from 15/09/06 ash venting and 05/02/10 Vulcanian explosion showed dominantly acicular swallowtail plagioclase microlites with occasional spherulitic and skeletal forms (Table. 1). Cristobalite was observed infilling vesicles and in the groundmass of vesicular ash only from the $27 / 07 / 05$ precursory explosion (Fig. 2).

\subsection{Quantitative microlite analysis}

Quantitative analysis of plagioclase microlite populations showed differences between tephra generated in various styles of explosive volcanism and effusive lava samples (Fig. 3; table 2). 
Data from each pyroclastic event formed small overlapping fields defining a broad trend in plagioclase $\mathrm{N}_{\mathrm{a}}$ (plagioclase area number density), $\phi$ (plagioclase area fraction), $\mathrm{S}_{\mathrm{n}}$ (characteristic plagioclase crystal size), and mean plagioclase aspect ratio, as defined in section 3 (Fig. 3a-c). The $27 / 07 / 2005$ precursory explosion yields the highest average pyroclastic $N_{a}$ values of $\sim 72,000 \mathrm{~mm}^{-2}$ (Fig. 3a). Ash venting and Vulcanian explosions show lower, but similar average $N_{a}$ values, between 21,000 to $30,000 \mathrm{~mm}^{-2}$. However, Vulcanian explosions show a greater range of $\mathrm{N}_{\mathrm{a}}$ values. The greater variability in Vulcanian explosions compared to ash venting is repeated for $\phi, S_{n}$, and mean plagioclase aspect ratio (Fig. 3a-c; Table. 2). Samples of the lava dome show $\mathrm{N}_{\mathrm{a}}$ values up to an order of magnitude higher than the tephra, with an average of $\sim 183,000 \mathrm{~mm}^{-2}$, and the largest range (Fig. 3a).

The $\phi$ vs $N_{a}$ trend for pyroclastic samples shows a positive line of best fit that approximately passes through the origin (Fig. 3a). Effusive samples in contrast have a line of best fit with a much steeper positive slope and a negative $\mathrm{Y}$-axis intercept (Fig. 3a).

The pyroclastic samples define a well constrained range for both $S_{n}$ and mean plagioclase aspect ratio with the lava dome samples showing lower $S_{n}$ and on average higher mean plagioclase aspect ratios (Fig. $3 \mathrm{~b}-\mathrm{c}$ ). The lava dome also shows a lower comparative range for both $S_{n}$ and mean aspect ratio (Fig. 3b-c; Table. 2). The higher $S_{n}$ and lower mean plagioclase aspect ratio of pyroclastic microlites indicate that they are in general larger and more elongate (acicular) compared with effusive microlites. This is also suggested by the similarity in $\phi$ of the tephra and lava dome samples but difference in $\mathrm{N}_{\mathrm{a}}$ (meaning the lower number microlites in the tephra must have been on average larger) and consistent with the results of visual examination of microlites (Table. 1).

\subsection{Crystal Size Distributions (CSD)}

All CSD plots show a generally concave-up shape (Fig. 4a) that can be broadly split into two or three crude straight-line sections, typically with a sharp down turn at the smallest crystal sizes (Fig. 4b). The sharp down turn at the smallest crystal sizes has been inferred to result from either an inadequate resolution to image the smallest crystal sizes (Marsh 1998; Hammer et al. 1999), or due to the reduced probability of intercepting smaller and smaller crystals (Cashman 1988; Brugger and Hammer 2010; Higgins 2011). Image resolution for this study is $1 \mu \mathrm{m}=9-10$ pixels. As such it seems unlikely that the downturn is the result of inadequate imaging. We therefore suggest the reduced probability of intercepting small crystals is the cause of the downturn in the CSDs.

Crystal size distributions presented here from differing eruption styles show distinct ranges for the slope and y-axis intercept $\left(n^{\circ}\right)$ of the left-hand steepest sections (Table 3), termed section 1 (Fig. 4 b). 
The lava dome samples have the highest $n^{\circ}$ of 24.99 to 26.90 , and the steepest slopes (-1308.1 to 804.1) (Fig. 4d, g, j; Table 3). Vulcanian explosion tephra show a range of $n^{\circ}$ values of 23.18 to 23.95 slopes of -749.87 and -528.68 (Fig. 4e, h, k; Table 3). Ash venting samples show the lowest $n^{\circ}$ values of 20.62 to 23.00 , and the shallowest slopes (-501.53 to -209.82) (Fig. 4c, f, i; Table 3).

At crystal sizes larger than 0.0084 to $0.012 \mathrm{~mm}$ the shape of the CSD trends for lava dome, Vulcanian explosion, and three ash venting (S2P9, S2P12, and S21P10) samples appear similar (Fig. 4a). While in contrast, the remaining ash venting samples (S2P13, S6P9, S216p, S21P7, and S21P9) have higher population densities for equivalent crystal sizes (i.e. more crystals of equivalent size), producing CSD trends that appear shallower and less concave (Fig. 4a).

Crystal size distributions from the same eruption style displayed here show strong similarities in the trend shape, along with the slope and $n^{\circ}$ of individual straight-line sections. Comparison between differing eruption styles however show large differences, dominantly at small crystal sizes, but in the case of ash venting also at larger crystal sizes. The implications of differences in the CSDs produced during varying styles of volcanism at SHV are explored in section 5.2.

\subsection{Magma ascent rates}

Ascent rate was calculated for four of the events examined here using the MND (microlite number density) water exsolution rate meter from Toramaru et al. (2008). As outlined in section 3.1 input values for $\mathrm{C}_{\mathrm{w}}$ and $\mathrm{C}_{\mathrm{si}}$ should reflect magma conditions at the microlite nucleation depth. The transition from growth to nucleation dominated crystallization at SHV was inferred by Clarke et al. (2007) from tephra produced by Vulcanian explosions in 1997 to be at $\sim 6-10 \mathrm{MPa}$. We therefore use a pressure of $10 \mathrm{MPa}$ to estimate $\mathrm{C}_{\mathrm{w}}$ giving a value of $1 \mathrm{wt} \%$ using VOLATILECALC from Newman and Lowenstern (2002).

Due to the restricted range of bulk magma composition erupted during the SHV eruption the value of $C_{s i}$ is unlikely to vary greatly between explosions (Christopher et al. 2014; Wadge et al. 2014). Bulk rock compositions from the 1995-present SHV eruption show $\mathrm{SiO}_{2}$ contents of $\sim 56$ to $62 \mathrm{wt} \%$ (Christopher et al. 2014; Wadge et al. 2014) with an approximate phenocryst content of $40 \%$ (Murphy et al. 2000). For $\mathrm{C}_{\mathrm{si}}$ a glass composition of $67.5 \mathrm{wt} \% \mathrm{SiO}_{2}$ is used when calculating magmatic ascent rates.

The calculated ascent rates for Vulcanian explosions vary between $0.0035-0.0006 \mathrm{~m} \mathrm{~s}^{-1}$, ash venting ascent rates overlap with this showing a range of $0.0020-0.0011 \mathrm{~m} \mathrm{~s}^{-1}$ (Table. 4). In contrast the lava dome has the highest calculated ascent rates of $0.014-0.0057 \mathrm{~m} \mathrm{~s}^{-1}$ (Table. 4), almost an order of magnitude higher than the pyroclastic samples. 
When discussing ascent rate in the following section we distinguish between a point estimate/value of magma ascent rate vs a time averaged one which may include periods of stalling/storage.

Therefore, the term 'magma ascent rate' will is used for the former value, and 'time averaged ascent rate' for the later situation.

The method outlined by Toramaru et al. (2008) was inferred to calculate a magma ascent rate at the microlite nucleation depth. However, since microlite crystallization occurs through much of magma ascent it seems likely that the value calculated here is an average dependent on the depth range and rate over which crystallization is occurring.. The values calculated here for ascent rate are therefore more likely closer to a 'time averaged ascent rate'.

\section{Discussion}

\subsection{Microlite textures}

Microlite textures are a product of the undercooling conditions in which they nucleated and grew, and can therefore be used to infer decompression conditions during magma ascent (e.g. Swanson 1977; Hammer et al. 2000; Szramek et al. 2006; Clarke et al. 2007; Toramaru et al. 2008; Preece et al. 2013; Renjith 2014). Here we use 2D microlite population statistics along with CSDs (inferred 3D) to deduce differences in the decompression pathway of magma erupted in contrasting eruption styles at a single volcano.

High $\mathrm{N}_{\mathrm{a}}$ and small microlites recorded in the lava dome samples (Fig. 3) point towards relatively nucleation dominated crystallization (Lofgren 1980; Hammer et al. 2000). The negative Y-axis intercept of the $\phi-\mathrm{N}_{\mathrm{a}}$ trend for the SHV lava dome samples (Fig. 3a) is characteristic of initially relatively-nucleation dominated crystallization that subsequently became growth dominated (Hammer et al. 2000). The high $\mathrm{N}_{\mathrm{a}}$ and small microlites in the lava dome samples suggest relatively rapid shallow microlite nucleation, probably in both the shallow conduit and while resident in the lava dome. The shallow microlite nucleation inferred here is likely driven by magma degassing during ascent leading to a rapid increase in magma liquidus generating high degrees of $\Delta T$. Subsequent slow cooling of the magma in the lava dome would have substantially decreased the degree of $\Delta T$, producing a period of crystal growth, as suggested by the effusive trend in Fig. $3 a$.

The large range of $\mathrm{N}_{\mathrm{a}}$ in lava dome samples suggests variable microlite nucleation densities and decompression rates during dome extrusion (Hammer et al. 2000; Toramaru et al. 2008). Such variation could result from the cyclic highly variable extrusion rates recorded during phase 5 of the SHV eruption (Odbert et al 2014; Stinton, et al. 2014a; Wadge et al. 2014). Extrusions rates are 
inferred to have reached a maximum $35 \mathrm{~m}^{3} \mathrm{~s}^{-1}$ (Odbert et al 2014) although the average rate for the entire eruption phase is $\sim 10 \mathrm{~m}^{3} \mathrm{~s}^{-1}$ (Wadge et al. 2014). Temporal variations in lava extrusion rate would be reflected in the rate of magma ascent and decompression, thus resulting in a range of microlite nucleation densities.

The precursory explosion has the highest $\mathrm{N}_{\mathrm{a}}$ and the smallest most equant crystals of the pyroclastic range (Fig. 3). Juvenile tephra in the precursory explosion also displays completely decayed amphiboles and a large amount of cristobalite (Fig. 2e), suggesting slow magma ascent (Rutherford and Hill 1993) and an extended period of vapor-phase fluxing of the magma (Horwell et al. 2013; Schipper et al. 2015) respectively. The precursory explosion examined here occurred weeks prior to the start of phase 3 of the SHV eruption at the end of a four and a half month precursory period (Wadge et al. 2014). The extended period of precursory activity is also suggestive of relatively slow initial magma ascent, consistent with microtextural evidence from the precursory explosion (Fig. 2e).

Microlites produced during Vulcanian explosions and syn-extrusive ash venting display the lowest $\mathrm{N}_{\mathrm{a}}$ values and the largest and most acicular microlites (Fig. 3), suggestive of a growth dominated system (Lofgren 1980). However, the $\phi-\mathrm{N}_{\mathrm{a}}$ trend for Vulcanian explosions and ash venting samples is close to intercepting the origin (Fig. 3a) indicating a relatively nucleation dominated system (Hammer et al. 2000). In both Vulcanian explosions and ash venting the apparent larger average microlite size visually appears to result from a lack of fine microlites (Fig 2a-d). A dearth of fine microlites is commonly observed in crystal populations generated during explosive activity (Hammer et al. 2000; Cassidy et al. 2015; Preece et al. 2016). The nucleation of fine microlites is a function of the degree of $\Delta T$ in the magma and the rate of crystallization, which are both in part controlled by the magma decompression rate and path (single step vs multistep), along with the duration of decompression, and the final pressure just before the explosion (e.g. Couch et al. 2003a; Couch et al. 2003b; Szramek et al. 2006; Noguchi et al. 2008; Toramaru et al. 2008; Brugger and Hammer 2010). During pyroclastic volcanism the rapid final decompression typically occurs over seconds to minutes followed by rapid quenching (Clarke et al. 2015). In contrast, experiments have shown crystallization timescales are typically hours to days (Couch, et al. 2003a, b; Brugger and Hammer 2010; Martel 2012). Therefore, during pyroclastic volcanism microlite nucleation in the shallow conduit is typically restricted by rapid decompression and quenching, although the exact processes vary because of conduit conditions. The restriction of crystallization in the shallow conduit therefore implies microlite textures in Vulcanian explosions and ash venting formed deeper in the conduit system reflecting deeper crystallization conditions. In comparison, microlite crystallization during dome effusion occurred over the entire conduit length, and likely also in the dome itself, thus recording conditions over the entire magma ascent path. 
Clarke et al. (2007) inferred a transition pressure from growth to nucleation dominated crystallization at SHV at 6-10 MPa. From this transition pressure we can estimate approximate depths which the microlite population of pyroclastic and effusive samples examined here reflect. A magma density of $1500 \mathrm{~kg} \mathrm{~m}^{-3}$ (Clarke et al. 2007) would translate to a depth of $\sim 410-680 \mathrm{~m}$. Given the uncertainty involved however, and the use of data from a different eruptive sequence, we suggest that the 'deeper magma system' is $>2 \mathrm{~km}$ and the 'shallower magma system' as $<1 \mathrm{~km}$.

\subsection{Crystal size distributions}

Crystal size distributions (CSD) record changes in crystallization processes during magma ascent (Marsh 1998; Melnik et al. 2011). Larger crystals are formed deeper in the magma system where slower decompression rates produces dominantly crystal growth (Marsh 1998; Melnik et al. 2011). In the shallow conduit decompression rate typically increases and crystal nucleation dominates (Geschwind and Rutherford 1995; Hammer et al. 1999; Clarke et al. 2007). Microlites of different sizes are therefore inferred to reflect magma decompression and $\Delta T$ conditions at various depths and can be used to infer magma decompression pathways.

The change in crystallization process through magma ascent is reflected in the shape of the CSD produced (Fig. 4). The CSDs of all samples examined here are concave upwards (Fig. 4), which is typically inferred to reflect the change from microlite growth to nucleation due to changes in $\Delta T$ as magma ascends (Marsh 1998). The curves are typically smooth rather than kinked (Fig. 4) suggesting a progressive change in crystallization and $\Delta T$ during ascent (Marsh 1998). As previously mentioned, the CSD trends in Fig. 4 can be approximated by two or three straight line sections, called section 1 to 3 , where section 1 is the left-most steepest section and section 3 in the right-most shallowest section (Fig. 4b). The y-axis intercept $\left(n^{\circ}\right)$ of each straight-line sections has been inferred to be indicative of microlite nucleation density, while the section slope $=-1 / G \tau$, where $G$ is growth rate and $\tau$ is crystallization time (Marsh 1998). Nucleation density and crystallization time reflect differing conditions depending on the section used. Section 1 at smaller microlite sizes reflects conditions in the shallow conduit, whereas sections 2 and 3 at larger crystal sizes record conditions deeper in the magma system.

Comparatively higher nucleation densities in section 1 of the lava dome samples, as implied by $n^{\circ}$ (Fig. 4), indicates high rates of microlite nucleation during shallow magma ascent. In contrast, nucleation rates in the shallow conduit for the pyroclastic samples are lower, both consistent with results from 2D microlite population analysis and inferences of restricted shallow nucleation during Vulcanian explosions and ash venting. However, differences in the slope and $n^{\circ}$ of section 1 between 
ash venting and Vulcanian explosions highlights different shallow conduit crystallization conditions not apparent in 2D microlite population analysis (Fig. 2a-d).

The lava dome, Vulcanian explosions, and three ash venting samples (S2P9, S2P12, and S21P10) display similar trends along with slopes and $n^{\circ}$ at crystals larger than $\sim 0.0084$ to $0.012 \mathrm{~mm}$ (sections 2 and 3) (Fig. 4a) despite strong differences in section 1. The matching CSD trends at larger crystal sizes indicates that despite contrasting eruption mechanisms the magma erupted in each experienced similar decompression and $\Delta T$ pathways deeper in the magmatic system. The four remaining ash venting samples (S2P13, S6P9, S216p, S21P7, and S21P9), however, display comparatively higher amounts of larger crystals, producing less concave CSD curves (Fig. 4). The increased population density of larger crystals in ash venting samples suggests a longer period of growth in the deeper magma system, indicative of comparatively slower magma decompression.

A range of distinct decompression pathways are recorded at SHV. Each eruption style examined here displays contrasting shallow conduit crystallization conditions with increasing degrees of nucleation from ash venting to Vulcanian explosions to lava effusion. In addition, two decompression pathways have been imaged deeper in the magma system with ash venting appearing to decompress more slowly.

\subsection{Ascent and eruption conditions}

Syn-extrusive ash venting has been inferred to occur because of shear induced fragmentation along the conduit margin and associated degassing during periods of rapid dome effusion (Cole et al. 2014a). The increased amount of large crystals however suggests a significant proportion of magma erupted during ash venting underwent increased crystal growth compared with the lava dome, implying slower decompression (Fig. 4). We infer the higher degree of crystal growth and slower decompression to result from decreased 'time averaged ascent rates' along the conduit margin (e.g. Calder et al. 2015) (Fig. 5). Friction with wall rock leads to slower magma ascent on the conduit margin compared with that insulated in the conduit center. Sluggish magma ascent along the conduit margin would result in decreased rates of decompression, compared with that in the conduit center, producing lower degrees of $\Delta T$ and therefore more crystal growth. Following the onset of brittle behavior, fracturing and fragmentation of the magma along the conduit margin in the shallow conduit forms zones of permeability. Outgassing through these permeable channel and entrainment of ash produces ash venting (Cole et al. 2014a) and rapidly quenches material on contact with air. The slower response time of crystallization (Couch, et al. 2003a, b; Brugger and Hammer 2010; Martel 2012) compared to eruption and quenching timescales during ash venting restricted the nucleation of small late stage microlites. Ash venting samples that displayed similar 
CSD trends to the lava dome potentially indicate the conduit margin fragmentation zone extends further into the conduit center than the zone of magma significantly slowed by friction (Fig. 5).

Magma extruded as the lava dome, occurring synchronously with syn-extrusive ash venting, is inferred to be from more rapidly ascending magma in the conduit center. Isolated from conduit wall friction the central part of the magma column ascends more rapidly therefore experiencing higher degrees of decompression and $\Delta T$. Moreover, relatively isothermal ascent in the shallow conduit, and slow cooling in the dome meant comparatively extensive microlite nucleation could occur. Differences in the microlite populations between synchronous lava effusion and ash venting are therefore inferred to result from contrasting decompression rates due to the magmas proximity to the conduit margin.

The similarity in CSD trends between Vulcanian explosions and the lava dome at large crystal sizes (larger than 0.0084 to $0.012 \mathrm{~mm}$; Fig. 4) likely indicates similar decompression and $\Delta T$ conditions in the deeper magma system (Fig. 5). Rapid decompression and quenching during eruption however then restricted microlite nucleation in the shallow conduit. The increased amount of small crystals in Vulcanian explosions compared to ash venting likely reflects either/or the higher degree of decompression and $\Delta T$ in the deeper magma system or, a period of conduit pressurization prior to eruption during which the magma was stalled at high $\Delta T$ and some nucleation may have occurred (Fig. 5). The similarity between Vulcanian explosions and the lava dome CSD trends at large crystal sizes (larger than 0.0084 to $0.012 \mathrm{~mm}$; Fig. 4) suggest that the difference between these eruptive styles at SHV is only produced in the shallow conduit, likely $<1 \mathrm{~km}$ depth (Fig. 5).

\subsection{Magma ascent rates}

Eruption processes are inferred to be a partial function of the magma ascent rate, with more rapid magma ascent generally associated with more explosive volcanism (e.g. Luhr 2002; Watts et al. 2002; Couch, Harford, et al. 2003; Rutherford and Devine 2003; Szramek et al. 2006; Toramaru et al. 2008; Miwa et al. 2009; Martel 2012; Scott et al. 2012; Wright et al. 2012; Lloyd et al. 2014; Cassidy et al. 2015; Scarlato et al. 2017; Cassidy et al. 2018). Rapid magma ascent typically allows less outgassing thus generating higher potential pressures required to drive violent gas expansion and fragmentation associated with explosive volcanism (e.g. Alatorre-lbargüengoitia et al. 2010; Bonadonna and Costa 2015). Slow ascent typically allows comparatively higher amounts of outgassing resulting in less energetic effusive volcanism (e.g. Castro and Gardner 2008; Cassidy et al. 2015). 
Ascent rates calculated here however define roughly the opposite trend, with lava dome effusion the highest while Vulcanian explosions and ash venting the slowest (Table. 4). We suggest that the reversal in the expected ascent rate trend is the result of microlite populations from differing eruptive activity sampling different windows during magma ascent.

As previously discussed, we suggest that microlite crystallization during Vulcanian explosions and ash venting dominantly occurred in the deep conduit system (> 2km depth), as rapid decompression during shallow ascent restricted crystallization. In contrast, during lava effusion slower decompression and slow cooling in the dome resulted in crystallization occurring over the entirety of magma ascent. The MND water exsolution rate meter uses $N_{v}$ to estimate the rate of decompression and ascent at the microlite nucleation depth (Toramaru et al. 2008). Therefore, differences in nucleation rate, or the depth at which nucleation occurs, will bias the measured $N_{v}$ to different periods or points during magma ascent. Data from pyroclastic eruptions are inferred to reflect slower magma 'time averaged ascent rates' deeper in the magma system. In contrast, effusive samples record syn-eruptive ascent in the shallow conduit suggesting rapid ascent and extrusion, in line with observations of rapid dome extrusion during phase 5 of the SHV eruption (Odbert et al 2014; Stinton, et al. 2014a; Wadge et al. 2014).

The results presented here suggest that differences in eruptive styles at SHV are controlled by notably shallow ( $<1 \mathrm{~km}$ depth) processes, which are now generally reflected in microlite populations.

\section{Conclusions}

We have presented analysis of microlite populations generated during a range of different styles of volcanism that straddle the explosive-effusive transition at SHV. These data show that:

1. The large difference between microlite populations generated during effusive and explosive volcanism is inferred to result from extremely rapid quenching in explosions, that restricts nucleation on eruption timescales.

2. The decompression pathways of magma erupted as the lava dome and in Vulcanian explosions is similar in the deeper magma system ( $>2 \mathrm{~km}$ depth). Differences between these eruption styles are restricted to the shallow conduit suggesting a shallow control $(<1 \mathrm{~km}$ depth) to eruption style at SHV.

3. During synchronous lava effusion and ash venting variations in 'time averaged ascent rates' due to conduit margin friction produce different decompression pathways resulting in contrasting microlite populations. Sluggish magma ascent along the conduit margin resulted 
in lower degrees of $\Delta T$ leading to comparatively more microlite growth. More rapid ascent in the conduit center along with slower cooling of the lava dome produced a higher degree of $\Delta T$ and more microlite nucleation.

4. Differences in the rate of crystallization over a magma's entire ascent means that microlite populations do not necessarily reflect the same depth range in each eruption style. At SHV this was most notably observed between effusive and pyroclastic activity where rapid decompression and quenching during pyroclastic activity restricts late stage crystallization. Pyroclastic microlite populations therefore reflect deeper conduit conditions ( $>2 \mathrm{~km}$ ) compared to effusive populations where extensive shallow crystallization can occur.

\section{Acknowledgements}

We would like to acknowledge the staff of Montserrat Volcano Observatory for assistance in collecting samples along with the staff of the Plymouth University Electron microscopy lab for their assistance. We also thank Mike Cassidy his comments on an earlier version of this manuscript. We appreciate comments from two anonymous reviewers that greatly improved this manuscript.

\section{References}

Alatorre-Ibargüengoitia, M.A., Scheu, B., Dingwell, D.B., Delgado-Granados, H., Taddeucci, J., 2010. Energy consumption by magmatic fragmentation and pyroclast ejection during Vulcanian eruptions. Earth Planet. Sci. Lett. 291, 60-69. https://doi.org/10.1016/j.epsl.2009.12.051

Bonadonna, C., Costa, A., 2015. Tephra Dispersal and Sedimentation, Second Edi. ed, The Encyclopedia of Volcanoes. Elsevier Inc. https://doi.org/10.1016/B978-0-12-385938-9.00033-X

Bonadonna, C., Mayberry, G.C., Calder, E.S., Sparks, R.S.J., Choux, C., Jackson, P., Lejeune, a. M., Loughlin, S.C., Norton, G.E., Rose, W.I., Ryan, G., Young, S.R., 2002. Tephra fallout in the eruption of Soufriere Hills Volcano, Montserrat. Geol. Soc. London, Mem. 21, 483-516. https://doi.org/10.1144/GSL.MEM.2002.021.01.22

Brugger, C.R., Hammer, J.E., 2010. Crystal size distribution analysis of plagioclase in experimentally decompressed hydrous rhyodacite magma. Earth Planet. Sci. Lett. 300, 246-254. https://doi.org/10.1016/j.epsl.2010.09.046

Calder, E.S., Lavallée, Y., Kendrick, J.E., Bernstein, M., 2015. Lava Dome Eruptions. Encycl. Volcanoes 343-362. https://doi.org/10.1016/B978-0-12-385938-9.00018-3

Cashman, K.V., 1988. Crystallization of Mount St. Helens 1980-1986 dacite: A quantitative textural approch. Bull Volcanol 50, 194-209.

Cashman, K. V., 1992. Groundmass crystallization of Mount St. Helens dacite, 1980-1986: a tool for interpreting shallow magmatic processes. Contrib. to Mineral. Petrol. 109, 431-449. https://doi.org/10.1007/BF00306547

Cashman, K. V, 2004. Volatile Controls on Magma Ascent and Eruption. State Planet Front. 
Challenges Geophys. Geophys. 19, 109-124. https://doi.org/10.1029/150gm10

Cassidy, M., Cole, P.D., Hicks, K.E., Varley, N.R., Peters, N., Lerner, A.H., 2015. Rapid and slow: Varying magma ascent rates as a mechanism for Vulcanian explosions. Earth Planet. Sci. Lett. 420, 73-84. https://doi.org/10.1016/j.epsl.2015.03.025

Cassidy, M., Manga, M., Cashman, K., Bachmann, O., 2018. Controls on explosive-effusive volcanic eruption styles. Nat. Commun. 9, 2839. https://doi.org/10.1038/s41467-018-05293-3

Castro, J.M., Gardner, J.E., 2008. Did magma ascent rate control the explosive-effusive transition at the Inyo volcanic chain, California? Geology 36, 279-282. https://doi.org/10.1130/G24453A.1

Christopher, T.E., Humphreys, M.C.S.S., Barclay, J., Genareau, K., De Angelis, S.M.H.H., Plail, M., Donovan, A., 2014. Petrological and geochemical variation during the Soufriere Hills eruption, 1995 to 2010. Geol. Soc. London, Mem. 39, 317-342. https://doi.org/10.1144/M39.17

Clarke, A.B., Ongaro, T.E., Belousov, A., 2015. Vulcanian Eruptions, Second Edi. ed, The Encyclopedia of Volcanoes. Elsevier Inc. https://doi.org/10.1016/B978-0-12-385938-9.00028-6

Clarke, A.B., Stephens, S., Teasdale, R., Sparks, R.S.J.J., Diller, K., 2007. Petrologic constraints on the decompression history of magma prior to Vulcanian explosions at the Soufrière Hills volcano, Montserrat. J. Volcanol. Geotherm. Res. 161, 261-274. https://doi.org/10.1016/j.jvolgeores.2006.11.007

Cole, P. D., Smith, P., Komorowski, J.-C., Alfano, F., Bonadonna, C., Stinton, A.J., Christopher, T., Odbert, H.M., Loughlin, S., 2014. Ash venting occurring both prior to and during lava extrusion at Soufriere Hills Volcano, Montserrat, from 2005 to 2010. Geol. Soc. London, Mem. 39, 71-92. https://doi.org/10.1144/M39.4

Cole, P D, Smith, P.J., Stinton, A.J., Odbert, H.M., Bernstein, M.L., Komorowski, J.C., Stewart, R., 2014. Vulcanian explosions at Soufrière Hills Volcano, Montserrat between 2008 and 2010. Geol. Soc. London, Mem. 39, 93-111. https://doi.org/10.1144/M39.5

Couch, S., Harford, C.L., Sparks, R.S.J., Carroll, M.R., 2003a. Experimental constraints on the conditions of formation of highly calcic plagioclase microlites at the Soufrire Hills Volcano, Montserrat. J. Petrol. 44, 1455-1475. https://doi.org/10.1093/petrology/44.8.1455

Couch, S., Sparks, R.S.J., Carroll, M.R., 2003b. The kinetics of degassing-induced crystallization at Soufriere Hills volcano, Montserrat. J. Petrol. 44, 1477-1502.

https://doi.org/10.1093/petrology/44.8.1477

Druitt, T.H., Young, S.R., Baptie, B., Bonadonna, C., Calder, E.S., Clarke, a. B., Cole, P.D., Harford, C.L., Herd, R. a., Luckett, R., Ryan, G., Voight, B., 2002. Episodes of cyclic Vulcanian explosive activity with fountain collapse at Soufriere Hills Volcano, Montserrat. Geol. Soc. London, Mem. 21, 281-306. https://doi.org/10.1144/GSL.MEM.2002.021.01.13

Geschwind, C.H., Rutherford, M.J., 1995. Crystallization of microlites during magma ascent: the fluid mechanics of 1980-1986 eruptions at Mount St Helens. Bull. Volcanol. 57, 356-370. https://doi.org/10.1007/BF00301293

Giordano, D., Nichols, A.R.L., Dingwell, D.B., 2005. Glass transition temperatures of natural hydrous melts: A relationship with shear viscosity and implications for the welding process. J. Volcanol. Geotherm. Res. 142, 105-118. https://doi.org/10.1016/j.jvolgeores.2004.10.015

Hammer, J.E., Cashman, K.V., Voight, B., 2000. Magmatic processes revealed by textural and compositional trends in Merapi dome lavas. J. Volcanol. Geotherm. Res. 100, 165-192. https://doi.org/10.1016/S0377-0273(00)00136-0 
Hammer, J.E., Cashman, K. V., Hoblitt, R.P., Newman, S., 1999. Degassing and microlite crystallization during pre-climactic events of the 1991 eruption of Mt. Pinatubo, Philippines. Bull. Volcanol. 60, 355-380. https://doi.org/10.1007/s004450050238

Hatter, S.J., Palmer, M.R., Gernon, T.M., Taylor, R.N., Cole, P.D., Barfod, D.N., Coussens, M., 2018. The Evolution of the Silver Hills Volcanic Center, and Revised40Ar/39Ar Geochronology of Montserrat, Lesser Antilles, With Implications for Island Arc Volcanism. Geochemistry, Geophys. Geosystems 19, 427-452. https://doi.org/10.1002/2017GC007053

Higgins, M.D., 2011. Textural coarsening in igneous rocks. Int. Geol. Rev. 53, 354-376. https://doi.org/10.1080/00206814.2010.496177

Higgins, M.D., 2000. Measurement of crystal size distributions. Am. Mineral. 85, 1105-1116. https://doi.org/10.2138/am-2000-8-901

Horwell, C.J., Williamson, B.J., Llewellin, E.W., Damby, D.E., Le Blond, J.S., 2013. The nature and formation of cristobalite at the Soufrière Hills volcano, Montserrat: Implications for the petrology and stability of silicic lava domes. Bull. Volcanol. 75, 1-19. https://doi.org/10.1007/s00445-013-0696-3

Kendrick, J.E., Lavallée, Y., Varley, N.R., Wadsworth, F.B., Lamb, O.D., Vasseur, J., 2016. Blowing Off Steam: Tuffisite Formation As a Regulator for Lava Dome Eruptions. Front. Earth Sci. 4, 1-15. https://doi.org/10.3389/feart.2016.00041

Lloyd, A.S., Ruprecht, P., Hauri, E.H., Rose, W., Gonnermann, H.M., Plank, T., 2014. NanoSIMS results from olivine-hosted melt embayments: Magma ascent rate during explosive basaltic eruptions. J. Volcanol. Geotherm. Res. 283, 1-18. https://doi.org/10.1016/j.jvolgeores.2014.06.002

Loughlin, S.C., Luckett, R., Ryan, G., Christopher, T., Hards, V., De Angelis, S., Jones, L., Strutt, M., 2010. An overview of lava dome evolution, dome collapse and cyclicity at Soufri??re Hills Volcano, Montserrat, 2005-2007. Geophys. Res. Lett. 37, 4-9. https://doi.org/10.1029/2010GL042547

Luhr, J.F., 2002. Petrology and geochemistry of the 1991 and 1998-1999 lava flows from Volcán de Colima, México: Implications for the end of the current eruptive cycle. J. Volcanol. Geotherm. Res. 117, 169-194. https://doi.org/10.1016/S0377-0273(02)00243-3

Marsh, B.D., 1998. On the interpretation of crystal size distributions in magmatic systems. J. Petrol. 39, 553-599. https://doi.org/10.1093/petroj/39.4.553

Martel, C., 2012. Eruption dynamics inferred from microlite crystallization experiments: Application to plinian and dome-forming eruptions of Mt. Pelée (martinique, lesser antilles). J. Petrol. 53, 699-725. https://doi.org/10.1093/petrology/egr076

Melnik, O.E., Blundy, J.D., Rust, A.C., Muir, D.D., 2011. Subvolcanic plumbing systems imaged through crystal size distributions. Geology 39, 403-406. https://doi.org/10.1130/G31691.1

Miwa, T., Toramaru, A., Iguchi, M., 2009. Correlations of volcanic ash texture with explosion earthquakes from vulcanian eruptions at Sakurajima volcano, Japan. J. Volcanol. Geotherm. Res. 184, 473-486. https://doi.org/10.1016/j.jvolgeores.2009.05.012

Morgan, D.J., Jerram, D.A., 2006. On estimating crystal shape for crystal size distribution analysis. J. Volcanol. Geotherm. Res. 154, 1-7. https://doi.org/10.1016/j.jvolgeores.2005.09.016

Mueller, S., Scheu, B., Spieler, O., Dingwell, D.B., 2008. Permeability control on magma fragmentation. Geology 36, 399-402. https://doi.org/10.1130/G24605A.1

Murphy, M.., Sparks, R.S.J., Barclay, J., Carroll, M.R., Brewer, T.S., 2000. Remobilization of Andesite 
Magma by Intrusion of Ma c Magma at the Soufriere Hills Volcano, Montserrat, West Indies. J. Petrol. 41, 21-42.

Newman, S., Lowenstern, J.B., 2002. Volatile Calc : a silicate melt - H2O - CO2 solution model written in Visual Basic for excel. Comput. Geosci. 28, 597-604. https://doi.org/doi:10.1016/S0098-3004(01)00081-4

Noguchi, S., Toramaru, A., Nakada, S., 2008. Relation between microlite textures and discharge rate during the 1991-1995 eruptions at Unzen, Japan. J. Volcanol. Geotherm. Res. 175, 141-155. https://doi.org/10.1016/j.jvolgeores.2008.03.025

Norton, G.E., Watts, R.B., Voight, B., Mattioli, G.S., Herd, R.A., Young, S.R., Devine, J.D., Aspinnall, W.P., Bonadonna, C., Baptie, B.J., Edmonds, M., Harford, C.L., Jolly, A.D., Loughlin, S.C., Luckett, R., Sparks, R.S.J., 2002. Pyroclastic flow and explosive activity at Soufrière Hills Volcano, Montserrat, during a period of virtually no magma extrusion (March 1998 to November 1999). Geol. Soc. London, Mem. 21, 467-481. https://doi.org/10.1144/GSL.MEM.2002.021.01.21

Preece, K., Barclay, J., Gertisser, R., Herd, R.A., 2013. Textural and micro-petrological variations in the eruptive products of the 2006 dome-forming eruption of Merapi volcano, Indonesia: Implications for sub-surface processes. J. Volcanol. Geotherm. Res. 261, 98-120. https://doi.org/10.1016/j.jvolgeores.2013.02.006

Preece, K., Gertisser, R., Barclay, J., Charbonnier, S.J., Komorowski, J.C., Herd, R.A., 2016. Transitions between explosive and effusive phases during the cataclysmic 2010 eruption of Merapi volcano, Java, Indonesia. Bull. Volcanol. 78. https://doi.org/10.1007/s00445-016-1046-z

Renjith, M.L., 2014. Micro-textures in plagioclase from 1994-1995 eruption, Barren Island Volcano: Evidence of dynamic magma plumbing system in the Andaman subduction zone. Geosci. Front. 5, 113-126. https://doi.org/10.1016/j.gsf.2013.03.006

Rutherford, M.J., Devine, J.D., 2003. Magmatic conditions and magma ascent as indicated by hornblende phase equilibria and reactions in the 1995-2002 Soufrière Hills magma. J. Petrol. 44, 1433-1454. https://doi.org/10.1093/petrology/44.8.1433

Rutherford, M.J., Hill, P.M., 1993. Magma ascent rates from amphibole breakdown: An experimental study applied to the 1980-1986 Mount St. Helens eruptions. J. Geophys. Res. Solid Earth 98, 19667-19685. https://doi.org/10.1029/93JB01613

Ryan, G.A., Loughlin, S.C., James, M.R., Jones, L.D., Calder, E.S., Christopher, T., Strutt, M.H., Wadge, G., 2010. Growth of the lava dome and extrusion rates at Soufriére Hills Volcano, Montserrat, West Indies: 2005-2008. Geophys. Res. Lett. 37, 0-4. https://doi.org/10.1029/2009GL041477

Scarlato, P., Mollo, S., Del Bello, E., von Quadt, A., Brown, R.J., Gutierrez, E., Martinez-Hackert, B., Papale, P., 2017. The 2013 eruption of Chaparrastique volcano (El Salvador): Effects of magma storage, mixing, and decompression. Chem. Geol. 448, 110-122. https://doi.org/10.1016/j.chemgeo.2016.11.015

Schipper, C.I., Castro, J.M., Tuffen, H., Wadsworth, F.B., Chappell, D., Pantoja, A.E., Simpson, M.P., Le Ru, E.C., 2015. Cristobalite in the 2011-2012 Cordón Caulle eruption (Chile). Bull. Volcanol. 77. https://doi.org/10.1007/s00445-015-0925-z

Scott, J.A.J., Mather, T.A., Pyle, D.M., Rose, W.I., Chigna, G., 2012. The magmatic plumbing system beneath Santiaguito Volcano, Guatemala. J. Volcanol. Geotherm. Res. 237-238, 54-68. https://doi.org/10.1016/j.jvolgeores.2012.05.014

Sparks, R.S.J.J., 1978. The dynamics of bubble formation and growth in magmas: A review and analysis. J. Volcanol. Geotherm. Res. 3, 1-37. https://doi.org/10.1016/0377-0273(78)90002-1 
Sparks, R.S.J.S.J., Young, S.R.R., 2002. The eruption of Soufriere Hills Volcano, Montserrat (19951999): overview of scientific results. Geol. Soc. London, Mem. 21, 45-69. https://doi.org/10.1144/gsl.mem.2002.021.01.03

Stinton, A.J., Cole, P.D., Odbert, H.M., Christopher, T., Avard, G., Bernstein, M., 2014a. Chapter 6 Dome growth and valley fill during Phase 5 (8 October 2009-11 February 2010) at the Soufriere Hills Volcano, Montserrat. Geol. Soc. London, Mem. 39, 113-131. https://doi.org/10.1144/M39.6

Stinton, A.J., Cole, P.D., Stewart, R.C., Odbert, H.M., Smith, P., 2014b. Chapter 7 The 11 February 2010 partial dome collapse at Soufriere Hills Volcano, Montserrat. Geol. Soc. London, Mem. 39, 133-152. https://doi.org/10.1144/M39.7

Swanson, S.E., 1977. Relation of nucleation and crystal-growth rate to the development of granitic textures. Am. Mineral. 62, 966-978.

Szramek, L., Gardner, J.E., Larsen, J., 2006. Degassing and microlite crystallization of basaltic andesite magma erupting at Arenal Volcano, Costa Rica. J. Volcanol. Geotherm. Res. 157, 182-201. https://doi.org/10.1016/j.jvolgeores.2006.03.039

Toramaru, A., Noguchi, S., Oyoshihara, S., Tsune, A., 2008. MND(microlite number density) water exsolution rate meter. J. Volcanol. Geotherm. Res. 175, 156-167. https://doi.org/10.1016/j.jvolgeores.2008.03.035

van Otterloo, J., Cas, R.A.F., Scutter, C.R., Otterloo, J. Van, Cas, R.A.F., Scutter, C.R., 2015. The fracture behaviour of volcanic glass and relevance to quench fragmentation during formation of hyaloclastite and phreatomagmatism. Earth-Science Rev. 151, 79-116. https://doi.org/10.1016/j.earscirev.2015.10.003

Wadge, G., Voight, B., Sparks, R.S.J., Cole, P.D., Loughlin, S.C., Robertson, R.E.A., 2014. Chapter 1 An overview of the eruption of Soufrière Hills Volcano, Montserrat from 2000 to 2010. Geol. Soc. London, Mem. 39, 1.1-40. https://doi.org/10.1144/M39.1

Watts, R.B., Herd, R.A., Sparks, R.S.J., Young, S.R., 2002. Growth patterns and emplacement of the andesitic lava dome at Soufrière Hills Volcano, Montserrat. Geol. Soc. London, Mem. 21, 115152. https://doi.org/10.1144/GSL.MEM.2002.021.01.06

Wright, H.M.N., Cashman, K. V., Mothes, P.A., Hall, M.L., Ruiz, A.G., Le Pennec, J.L., 2012. Estimating rates of decompression from textures of erupted ash particles produced by 1999-2006 eruptions of Tungurahua volcano, Ecuador. Geology 40, 619-622. https://doi.org/10.1130/G32948.1

\section{Figure captions}

Fig. 1 A topographic map of Montserrat showing the current vent at English's Crater (red), along with the sampling locations for tephra analyzed (yellow). Sample componentry is shown for each sample location where vesicular ash is red and crystalline ash blue. Inset a regional map of the Lesser Antilles Arc, showing the location of Montserrat. 
Fig. 2 Representative SEM back scatter electron images for material produced in each eruption sample. The interpreted SEM BSE image highlighting vesicles (pink), plagioclase (blue), pyroxene and oxides (yellow), and cristobalite (orange) crystals is shown alongside.

Fig. 3 Variation in microlite textural and population characteristics between samples as denoted by the relationship between (a) $N_{a}$ and $\phi$, (b) $N_{a}$ and $S_{n}$, and (c) $N_{a}$ and aspect ratio. The general trends of the effusive (1) (lava dome) and explosive (2) (ash venting, Vulcanian explosion, and precursory explosion) data fields are shown in (a). The fields denotated by variation within each event are shown. Each point denotes data taken from a different grain within a single sample from each eruption. In Fig. 3c an anomalously mean aspect ratio high result is observed in the 10th Jan 2010 Vulcanian explosion sample

Fig. 4 The result of CSD analysis from samples of ash venting, the lava dome, and Vulcanian explosions in which more than 200 microlites were outlined (a). Each CSD trend can be broadly broken up in to two or three straight line sections (b). Crystal size distributions for all Ash venting (c), lava dome (d), and Vulcanian explosion (e) samples that showed more than 200 outlined crystal in an image. Two representative CSDs are shown for each eruption style (ash venting: $\mathrm{f}, \mathrm{i}$, lava dome: $\mathrm{g}$, j, Vulcanian explosion: $h, k$ ) along with the slope, $n^{\circ}$, and $R^{2}$ for the left hand steepest straight-line section and the total number of counted crystals $(n)$.

Fig. 5 Summary model displaying the inferred conduit conditions during both syn-extrusive ash venting and Vulcanian explosions. Two inserts show a detailed view of conduit conditions during synextrusive ash venting and graph of crystal growth/nucleation vs undercooling with 4 points denoted inferred to roughly reflect conditions at various places in both eruption styles. (a) In the deeper conduit ( $>2 \mathrm{~km}$ depth) decompression conditions appear similar for both Vulcanian explosions and the lava dome. (b) Differences in magma decompression pathway are instead restricted to the shallow conduit ( $<1 \mathrm{~km}$ depth), suggesting a shallow control to eruption style at SHV. (c) Despite apparently similar input magma the rapid decompression and quenching of magma during Vulcanian explosions restricts the nucleation of fine microlites. (d) In contrast difference during syn-extrusive ash venting are the result of lower rates of decompression rates because of slower 'time averaged ascent rates' on the conduit margin in the deep magma system leading to increased crystal. (e) Shear induce brittle fracturing however leads to rapid decompression and quenching of conduit margin magma. Material in the conduit center also undergoes rapid decompression but cools more slowly resulting in higher microlite nucleation. 
Table. 1 Summary of the plagioclase, pyroxene and oxide microlite textures for each sample used in this study along with the eruption date and style that produced them, and the location from which the samples were taken.

Table. 2 The results of 2D plagioclase microlites analysis from ImageJ.

Table. 3 The results of CSD analysis. For each sample the slope, $n^{\circ}$, and $\mathrm{R}^{2}$ value are shown for each of the straight-line sections identified from the CSD trend.

${ }^{1}$ is the number of crystals counted in each analysis

${ }^{2}$ the number in the brackets is the $\mathrm{R}^{2}$ from CSDslice for 3D aspect ratio confidence

Table. 4 Input parameters and results for magma ascent rates calculated using Toramaru et al., (2008). 


\begin{tabular}{|c|c|c|c|c|}
\hline $\begin{array}{r}\text { Date } \\
\text { (eruption } \\
\text { phase) }\end{array}$ & Eruption type & $\begin{array}{l}\text { Sample } \\
\text { collecti } \\
\text { on } \\
\text { locatio } \\
\text { n }\end{array}$ & $\begin{array}{l}\text { Plagioclase microlite } \\
\text { morphology }\end{array}$ & $\begin{array}{l}\text { Other microlite } \\
\text { morphology }\end{array}$ \\
\hline $\begin{array}{r}04-J a n-2010 \\
(5)\end{array}$ & $\begin{array}{l}\text { Syn- eruptive } \\
\text { Ash venting }\end{array}$ & $\begin{array}{l}\text { Monts } \\
\text { errat } \\
\text { Volcan } \\
\text { o } \\
\text { Observ } \\
\text { atory }\end{array}$ & Tabular (hopper) & Tabular, (hopper) \\
\hline $\begin{array}{r}15-S e p t-2006 \\
(3)\end{array}$ & $\begin{array}{l}\text { Syn- eruptive } \\
\text { Ash venting }\end{array}$ & $\begin{array}{l}\text { St. } \\
\text { George } \\
\text { 's Hill }\end{array}$ & $\begin{array}{l}\text { Tabular, spherulitic, } \\
\text { acicular, hopper, (skeletal) }\end{array}$ & $\begin{array}{l}\text { Tabular, spherulitic, } \\
\text { acicular, hopper }\end{array}$ \\
\hline $\begin{array}{r}10-J a n-2010 \\
\text { (5) }\end{array}$ & $\begin{array}{l}\text { Vulcanian } \\
\text { Explosion }\end{array}$ & $\begin{array}{l}\text { Monts } \\
\text { errat } \\
\text { Volcan } \\
\text { o } \\
\text { Observ } \\
\text { atory }\end{array}$ & Tabular, (hopr & $\begin{array}{l}\text { Tabular, acicular, } \\
\text { prismatic, (hopper) }\end{array}$ \\
\hline $\begin{array}{r}05-F e b-2010 \\
\text { (5) }\end{array}$ & $\begin{array}{l}\text { Vulcanian } \\
\text { Explosion }\end{array}$ & $\begin{array}{l}\text { Fergus } \\
\text { Ridge }\end{array}$ & $\begin{array}{l}\text { Tabular, spherulitic, hopper, } \\
\text { acicular, (skeletal) }\end{array}$ & $\begin{array}{l}\text { Tabular, spherulitic, } \\
\text { hopper, (skeletal) }\end{array}$ \\
\hline $\begin{array}{r}27-J u l-2005 \\
(3)\end{array}$ & $\begin{array}{l}\text { Precursor } \\
\text { explosion }\end{array}$ & $\begin{array}{l}\text { Vuepoi } \\
\text { nt } \\
\text { Hotel }\end{array}$ & Tabular, hopper & Tabular, (hopper) \\
\hline $2010(5)$ & Lava Dome & $\begin{array}{l}\text { Block } \\
\text { and } \\
\text { ash } \\
\text { flow - } \\
\text { Trants }\end{array}$ & Tabular & Tabular \\
\hline
\end{tabular}


Table. 1 Summary of the plagioclase, pyroxene and oxide microlite textures for each sample used in this study along with the eruption date and style that produced them, and the location from which the samples were taken. 


\begin{tabular}{|c|c|c|c|c|c|c|c|}
\hline $\begin{array}{r}\text { Dat } \\
\text { e }\end{array}$ & $\begin{array}{l}\text { Eruption } \\
\text { type }\end{array}$ & $\begin{array}{r}\text { Total } \\
\text { Plagioclase } \\
\text { Microlites } \\
\text { Counted }\end{array}$ & $\begin{array}{r}\text { Microlite } \\
\text { Number } \\
\text { Density, } \mathrm{N}_{\mathrm{a}} \\
\left(\mathrm{mm}^{-2}\right)\end{array}$ & $\begin{array}{r}\text { Volumetric } \\
\text { Number } \\
\text { Density, } \mathrm{N}_{\mathrm{v}} \\
\left(\mathrm{mm}^{-3}\right)\end{array}$ & $\begin{array}{r}\text { Plagiocla } \\
\text { se area } \\
\text { Fraction, } \\
\Phi\end{array}$ & $\begin{array}{r}\text { Mean } \\
\text { Microlite } \\
\text { Size, } S_{n} \\
(\mu \mathrm{m})\end{array}$ & $\begin{array}{r}\text { Mean } \\
\text { Aspect } \\
\text { Ratio } \\
(\mathrm{s} / \mathrm{l})\end{array}$ \\
\hline \multirow{5}{*}{$\begin{array}{r}04- \\
\text { Jan- } \\
201 \\
0\end{array}$} & \multirow{5}{*}{$\begin{array}{l}\text { Syn- } \\
\text { eruptive } \\
\text { Ash } \\
\text { venting }\end{array}$} & 142 & 28,663 & $11,417,066$ & 0.181 & 2.511 & 0.37 \\
\hline & & 272 & 15,870 & $5,143,228$ & 0.193 & 3.086 & 0.38 \\
\hline & & 342 & 41,748 & $13,851,921$ & 0.379 & 3.014 & 0.44 \\
\hline & & 438 & 34,721 & $12,524,349$ & 0.267 & 2.772 & 0.43 \\
\hline & & 318 & 26,616 & $7,263,236$ & 0.357 & 3.665 & 0.45 \\
\hline \multirow{5}{*}{$\begin{array}{r}15- \\
\text { Sept } \\
- \\
200 \\
6\end{array}$} & \multirow{5}{*}{$\begin{array}{l}\text { Syn- } \\
\text { eruptive } \\
\text { Ash } \\
\text { venting }\end{array}$} & 202 & 17,612 & $7,315,588$ & 0.102 & 2.407 & 0.22 \\
\hline & & 269 & 28,187 & $14,767,218$ & 0.103 & 1.909 & 0.20 \\
\hline & & 274 & 27,695 & $13,660,557$ & 0.114 & 2.027 & 0.27 \\
\hline & & 297 & 33,029 & $18,640,002$ & 0.104 & 1.772 & 0.27 \\
\hline & & 459 & 40,683 & $18,199,189$ & 0.203 & 2.235 & 0.41 \\
\hline \multirow{6}{*}{$\begin{array}{r}10- \\
\text { Jan- } \\
201 \\
0\end{array}$} & \multirow{6}{*}{$\begin{array}{l}\text { Vulcanian } \\
\text { Explosion }\end{array}$} & 168 & 19,117 & $63,39,042$ & 0.174 & 3.016 & 0.36 \\
\hline & & 138 & 9,380 & $2,487,644$ & 0.133 & 3.771 & 0.35 \\
\hline & & 113 & 12,632 & 2,980,097 & 0.227 & 4.239 & 0.81 \\
\hline & & 680 & 57,988 & $23,757,295$ & 0.345 & 2.441 & 0.49 \\
\hline & & 497 & 30,078 & $15,408,895$ & 0.115 & 1.952 & 0.45 \\
\hline & & 450 & 37,719 & $15,456,468$ & 0.225 & 2.440 & 0.52 \\
\hline \multirow{5}{*}{$\begin{array}{r}05- \\
\text { Feb- } \\
201 \\
0\end{array}$} & \multirow{5}{*}{$\begin{array}{l}\text { Vulcanian } \\
\text { Explosion }\end{array}$} & 180 & 19,015 & $7,154,865$ & 0.134 & 2.658 & 0.44 \\
\hline & & 458 & 49,766 & $23,893,479$ & 0.216 & 2.083 & 0.49 \\
\hline & & 152 & 11,250 & $4,715,460$ & 0.064 & 2.386 & 0.30 \\
\hline & & 78 & 6,093 & $1,685,930$ & 0.080 & 3.614 & 0.30 \\
\hline & & 130 & 19,180 & $7,639,405$ & 0.121 & 2.511 & 0.37 \\
\hline \multirow{4}{*}{$\begin{array}{r}27- \\
\text { Jul- } \\
200 \\
5\end{array}$} & \multirow{4}{*}{$\begin{array}{l}\text { Precursor } \\
\text { Explosion }\end{array}$} & 639 & 54,801 & $23,972,012$ & 0.286 & 2.286 & 0.42 \\
\hline & & 918 & 79,234 & $35,537,050$ & 0.394 & 2.230 & 0.42 \\
\hline & & 1103 & 87,609 & $41,592,810$ & 0.389 & 2.106 & 0.38 \\
\hline & & 564 & 65,276 & $3,3051,443$ & 0.255 & 1.975 & 0.44 \\
\hline \multirow{8}{*}{$\begin{array}{r}201 \\
0\end{array}$} & \multirow{8}{*}{$\begin{array}{l}\text { Lava Dome } \\
\text { (block and } \\
\text { ash flows) }\end{array}$} & 1265 & 109,287 & $69,711,142$ & 0.269 & 1.568 & 0.49 \\
\hline & & 1986 & 141,422 & $109,134,155$ & 0.237 & 1.296 & 0.52 \\
\hline & & 2015 & 176,497 & $132,824,510$ & 0.312 & 1.329 & 0.55 \\
\hline & & 1279 & 182,176 & $143,001,452$ & 0.296 & 1.274 & 0.49 \\
\hline & & 1551 & 263,920 & $249,870,363$ & 0.294 & 1.056 & 0.55 \\
\hline & & 1114 & 122,499 & $88,559,701$ & 0.234 & 1.383 & 0.53 \\
\hline & & 2112 & 202,895 & $172,316,440$ & 0.281 & 1.177 & 0.55 \\
\hline & & 2169 & 197,140 & $151,814,775$ & 0.332 & 1.299 & 0.53 \\
\hline
\end{tabular}




\begin{tabular}{llllll}
2969 & 204,171 & $180,964,932$ & 0.260 & 1.128 & 0.53 \\
3200 & 232,626 & $192,005,342$ & 0.341 & 1.212 & 0.53 \\
\hline
\end{tabular}

Table. 2 The results of 2D plagioclase microlites analysis from ImageJ. 


\begin{tabular}{|c|c|c|c|c|c|c|c|c|c|c|c|c|c|c|}
\hline \multirow[b]{2}{*}{ Date } & \multirow[b]{2}{*}{$\begin{array}{l}\text { Erup } \\
\text { tion } \\
\text { style }\end{array}$} & \multirow[b]{2}{*}{$\begin{array}{r}\mathrm{Sa} \\
\mathrm{mpl} \\
\mathrm{e}\end{array}$} & \multirow[b]{2}{*}{$n^{1}$} & \multirow[b]{2}{*}{$\begin{array}{r}\text { Meas } \\
\text { ured } \\
\text { area } \\
\left(\mu \mathrm{m}^{2}\right)\end{array}$} & \multirow[b]{2}{*}{$\begin{array}{r}\text { Aspect } \\
\text { ratio }\left(R^{2}\right)^{2}\end{array}$} & \multicolumn{3}{|c|}{ Section 1} & \multicolumn{3}{|c|}{ Section 2} & \multicolumn{3}{|c|}{ Section 3} \\
\hline & & & & & & $\begin{array}{l}\operatorname{In}( \\
\left.n^{\circ}\right) \\
\left(m^{2}\right. \\
m^{-} \\
\left.{ }^{4}\right)\end{array}$ & $\begin{array}{l}\text { Slo } \\
\text { pe } \\
\left({ }^{\circ}\right)\end{array}$ & $\mathbf{R}^{2}$ & $\begin{array}{l}\text { In( } \\
\left.n^{\circ}\right) \\
(m \\
m^{-} \\
\left.{ }^{4}\right)\end{array}$ & $\begin{array}{l}\text { Slo } \\
\text { pe } \\
\left({ }^{\circ}\right)\end{array}$ & $\mathbf{R}^{2}$ & $\begin{array}{l}\text { In( } \\
\left.n^{0}\right) \\
\left(m^{2}\right. \\
m^{-} \\
\left.{ }^{4}\right)\end{array}$ & $\begin{array}{c}\text { Slo } \\
\text { pe } \\
\left({ }^{\circ}\right)\end{array}$ & $\mathbf{R}^{2}$ \\
\hline \multirow{11}{*}{$\begin{array}{l}04 / 0 \\
1 / 10\end{array}$} & \multirow{11}{*}{$\begin{array}{l}\text { Syn- } \\
\text { extru } \\
\text { sive } \\
\text { ash } \\
\text { venti } \\
\text { ng }\end{array}$} & $2-$ & 27 & 1430 & 1.00:1.70:3. & 21. & - & 0. & & & & 17. & - & 1 \\
\hline & & $9 p$ & 1 & 4.33 & $00(0.77)$ & 55 & 305 & 9 & & & & 22 & 105 & \\
\hline & & & & & & & .73 & 9 & & & & & .34 & \\
\hline & & 2- & 33 & 1558 & 1.00:1.15:2. & 22. & - & 0. & 20. & - & 0. & 17. & - & 1 \\
\hline & & $12 p$ & 4 & 7.88 & $00(0.77)$ & 08 & 402 & 9 & 80 & 266 & 99 & 06 & 94. & \\
\hline & & & & & & & .68 & 9 & & .9 & & & 57 & \\
\hline & & 2- & 41 & 1330 & 1.00:1.30:3. & 22. & - & 0. & 21. & - & 1. & 19. & - & 1 \\
\hline & & $13 p$ & 7 & 0.77 & $20(0.76)$ & 47 & 343 & 9 & 05 & 227 & 00 & 32 & 139 & \\
\hline & & & & & & & .43 & 9 & & .4 & & & .66 & \\
\hline & & 6,9 & 29 & 1725 & 1.00:1.40:3. & 20. & & 0. & & & & 18. & 123 & 1 \\
\hline & & & 3 & 0.41 & $40(0.74)$ & 62 & $\begin{array}{r}209 \\
.82 \\
\end{array}$ & $\begin{array}{l}9 \\
7\end{array}$ & & & & 76 & .01 & \\
\hline \multirow{12}{*}{$\begin{array}{l}15 / 0 \\
9 / 06\end{array}$} & \multirow{12}{*}{$\begin{array}{l}\text { Syn- } \\
\text { extru } \\
\text { sive } \\
\text { ash } \\
\text { venti } \\
\text { ng }\end{array}$} & 21- & 26 & 1195 & $1.00: 3.00: 1$ & 21. & - & 0. & & & & 16. & - & 1 \\
\hline & & $6 p$ & 6 & 5.18 & $0.00(0.70)$ & 88 & 278 & 9 & & & & 94 & 62. & \\
\hline & & & & & & & .95 & 9 & & & & & 82 & \\
\hline & & 21- & 26 & 1118 & $1.00: 3.40: 1$ & 21. & - & 0. & 20. & - & 0. & 19. & - & 0. \\
\hline & & $7 p$ & 4 & 1.84 & $0.00(0.59)$ & 88 & 305 & 9 & 82 & 202 & 99 & 95 & 157 & 9 \\
\hline & & & & & & & .28 & 9 & & .39 & & & .69 & 9 \\
\hline & & 21- & 29 & 1347 & $1.00: 2.00: 7$ & 21. & & 0. & & & & 17. & - & 1 \\
\hline & & $9 p$ & 7 & 6.53 & $00(0.60)$ & 32 & 238 & 9 & & & & 93 & 116 & \\
\hline & & & & & & & .26 & 9 & & & & & .97 & \\
\hline & & $21-$ & 44 & 1553 & $1.00: 1.50: 3$. & 23. & & 0. & & & & 20. & - & 0. \\
\hline & & $10 p$ & 1 & 0.54 & $00(0.77)$ & 00 & 501 & 9 & & & & 3 & 238 & 9 \\
\hline & & & & & & & .53 & 9 & & & & & .54 & 9 \\
\hline $10 / 0$ & Vulca & 8- & 65 & 1520 & $1.00: 1.30: 2$ & 23. & - & 0. & 21. & - & 1. & 18. & - & 1 \\
\hline \multirow[t]{8}{*}{$1 / 10$} & \multirow{8}{*}{$\begin{array}{l}\text { nian } \\
\text { explo } \\
\text { sion }\end{array}$} & 29 & 4 & 0.60 & $10(0.85)$ & 85 & 652 & 9 & 77 & 395 & 00 & 95 & 177 & \\
\hline & & & & & & & .78 & 9 & & .74 & & & .63 & \\
\hline & & $8-$ & 47 & 2016 & $1.00: 1.50: 2$ & 23. & - & 0. & & & & 19. & - & 0. \\
\hline & & 31 & 2 & 5.27 & $50(0.80)$ & 51 & 749 & 9 & & & & 02 & 198 & 9 \\
\hline & & & & & & & .87 & 9 & & & & & .76 & 9 \\
\hline & & $10-$ & 41 & 1231 & $1.00: 1.30: 2$ & 23. & - & 1. & & & & 20. & - & 0 . \\
\hline & & $2 p$ & 9 & 7.36 & $60(0.84)$ & 18 & 528 & 0 & & & & 36 & 220 & 9 \\
\hline & & & & & & & .68 & 0 & & & & & .27 & 9 \\
\hline $05 / 0$ & Vulca & $13-$ & 45 & 1008 & $1.00: 1.25: 2$ & 23. & - & 0. & 22. & - & 0. & 19. & - & 1 \\
\hline $2 / 10$ & nian & $11 p$ & 9 & 1.92 & $30(0.83)$ & 95 & 670 & 9 & 21 & 395 & 99 & 17 & 185 & \\
\hline & $\begin{array}{l}\text { explo } \\
\text { sion }\end{array}$ & & & & & & .45 & 9 & & .94 & & & .06 & \\
\hline
\end{tabular}




\begin{tabular}{|c|c|c|c|c|c|c|c|c|c|c|c|c|c|c|}
\hline Phas & Lava & 15- & 11 & 1420 & $1.00: 1.25: 2$ & 24. & - & 0. & 23. & - & 0. & 19. & - & 1 \\
\hline \multirow[t]{29}{*}{ e 5} & dom & P5 & 88 & 0.55 & $10(0.84)$ & 99 & 804 & 9 & 17 & 489 & 99 & 19 & 187 & \\
\hline & e & 2 & & & & & .1 & 9 & & .06 & & & .18 & \\
\hline & & $15-$ & 18 & 1282 & 1.00:1.25:2. & 25. & - & 1. & 21. & - & 0. & 16. & - & 1 \\
\hline & & P5_ & 93 & 7.83 & $10(0.88)$ & 91 & 982 & 0 & 03 & 287 & 99 & 63 & 76. & \\
\hline & & 3 & & & & & .31 & 0 & & .67 & & & 80 & \\
\hline & & 15- & 18 & 1387 & 1.00:1.20:1. & 25 . & - & 0. & 24. & - & 1. & 20. & - & 0. \\
\hline & & P5_ & 57 & 3.96 & $80(0.91)$ & 94 & 109 & 9 & 03 & 682 & 00 & 97 & 295 & 9 \\
\hline & & 4 & & & & & 6.1 & 8 & & .14 & & & .72 & 8 \\
\hline & & $15-$ & 12 & 9596. & 1.00:1.30:2. & 26. & - & 0. & 22. & - & 0. & 15. & - & 1 \\
\hline & & P5_ & 08 & 02 & $10(0.90)$ & 12 & 110 & 9 & 01 & 361 & 98 & 87 & 51. & \\
\hline & & 5 & & & & & 1.6 & 9 & & .73 & & & 67 & \\
\hline & & $15-$ & 14 & 1013 & 1.00:1.25:1. & 26. & - & 0. & 23. & - & 1. & & & \\
\hline & & P5_ & 94 & 1.34 & $90(0.92)$ & 51 & 129 & 9 & 12 & 560 & 00 & & & \\
\hline & & 7 & & & & & 0.3 & 9 & & .3 & & & & \\
\hline & & 16- & 10 & 1204 & 1.00:1.20:1. & 25. & - & 1. & 23. & - & 1. & 17. & - & 1 \\
\hline & & P5_ & 22 & 0.06 & $90(0.89)$ & 96 & 125 & 0 & 12 & 570 & 00 & 01 & 89. & \\
\hline & & 5 & & & & & 8.3 & 0 & & .56 & & & 19 & \\
\hline & & $16-$ & 19 & 1171 & 1.00:1.25:1. & 26. & - & 0. & 23. & - & 0. & 19. & - & 1 \\
\hline & & P5_ & 98 & 4.76 & $90(0.88)$ & 72 & 130 & 9 & 26 & 538 & 99 & 54 & 228 & \\
\hline & & 6 & & & & & 8.1 & 9 & & .36 & & & .17 & \\
\hline & & $16-$ & 20 & 1464 & $1.00: 1.25: 2$. & 25. & - & 0. & 23. & - & 1. & 18. & - & 0. \\
\hline & & P5_ & 49 & 3.50 & $10(0.86)$ & 81 & 957 & 9 & 54 & 539 & 00 & 16 & 134 & 9 \\
\hline & & 7 & & & & & .23 & 9 & & .95 & & & .63 & 8 \\
\hline & & 16- & 28 & 1318 & 1.00:1.25:1. & 26. & - & 0. & 23. & - & 0. & 19. & - & 1 \\
\hline & & P5_ & 16 & 2.63 & $90(0.95)$ & 90 & 122 & 9 & 69 & 589 & 99 & 47 & 236 & \\
\hline & & 11 & & & & & 9.3 & 9 & & .58 & & & .62 & \\
\hline & & $16-$ & 30 & 1445 & 1.00:1.30:2. & 26. & - & 0. & 23. & - & 0. & 18. & - & 1 \\
\hline & & P5_ & 34 & 2.76 & $10(0.89)$ & 81 & 109 & 9 & 81 & 548 & 99 & 73 & 146 & \\
\hline & & 12 & & & & & 5.2 & 9 & & .52 & & & .05 & \\
\hline
\end{tabular}

Table. 3 The results of CSD analysis. For each sample the slope, $n^{\circ}$, and $\mathrm{R}^{2}$ value are shown for each of the straight-line sections identified from the CSD trend.

${ }^{1}$ is the number of crystals counted in each analysis

${ }^{2}$ the number in the brackets is the $\mathrm{R}^{2}$ from CSDslice for 3D aspect ratio confidence 


\begin{tabular}{|l|l|l|l|l|l|l|}
\hline & $\mathrm{N}_{\mathrm{v}}\left(\mathrm{m}^{-3}\right)$ & $\rho\left(\mathrm{kg} \mathrm{m}^{-3}\right)$ & $\mathrm{C}_{\mathrm{si}}$ & $\mathrm{C}_{\mathrm{w}}$ & $\begin{array}{l}\text { Decompression } \\
\text { rate }\left(\mathrm{Pa} \mathrm{s}^{-1}\right)\end{array}$ & Ascent rate $\left(\mathrm{m} \mathrm{s}^{-1}\right)$ \\
\hline $\begin{array}{l}4 / 01 / 2010- \\
\text { Ash venting }\end{array}$ & $\begin{array}{l}1.4 \times 10^{16}- \\
5.1 \times 10^{15}\end{array}$ & 2138 & 67.5 & 1 & $43-22$ & $0.0020-0.0011$ \\
\hline $\begin{array}{l}10 / 01 / 2010 \\
- \text { Vulcanian } \\
\text { explosion }\end{array}$ & $\begin{array}{l}2.4 \times 10^{16}- \\
2.5 \times 10^{15}\end{array}$ & 2415 & 67.5 & 1 & $61-14$ & $0.0026-0.0006$ \\
\hline $\begin{array}{l}5 / 02 / 2010- \\
\text { Vulcanian } \\
\text { explosion }\end{array}$ & $\begin{array}{l}2.4 \times 10^{16}- \\
1.7 \times 10^{15}\end{array}$ & 1804 & 67.5 & 1 & $62-11$ & $0.0035-0.0006$ \\
\hline Lava Dome & $\begin{array}{l}1.9 \times 10^{17}- \\
7.0 \times 10^{16}\end{array}$ & 2219 & 67.5 & 1 & $126-295$ & $0.014-0.0057$ \\
\hline
\end{tabular}

Table. 4 Input parameters and results for magma ascent rates calculated using Toramaru et al., (2008). 


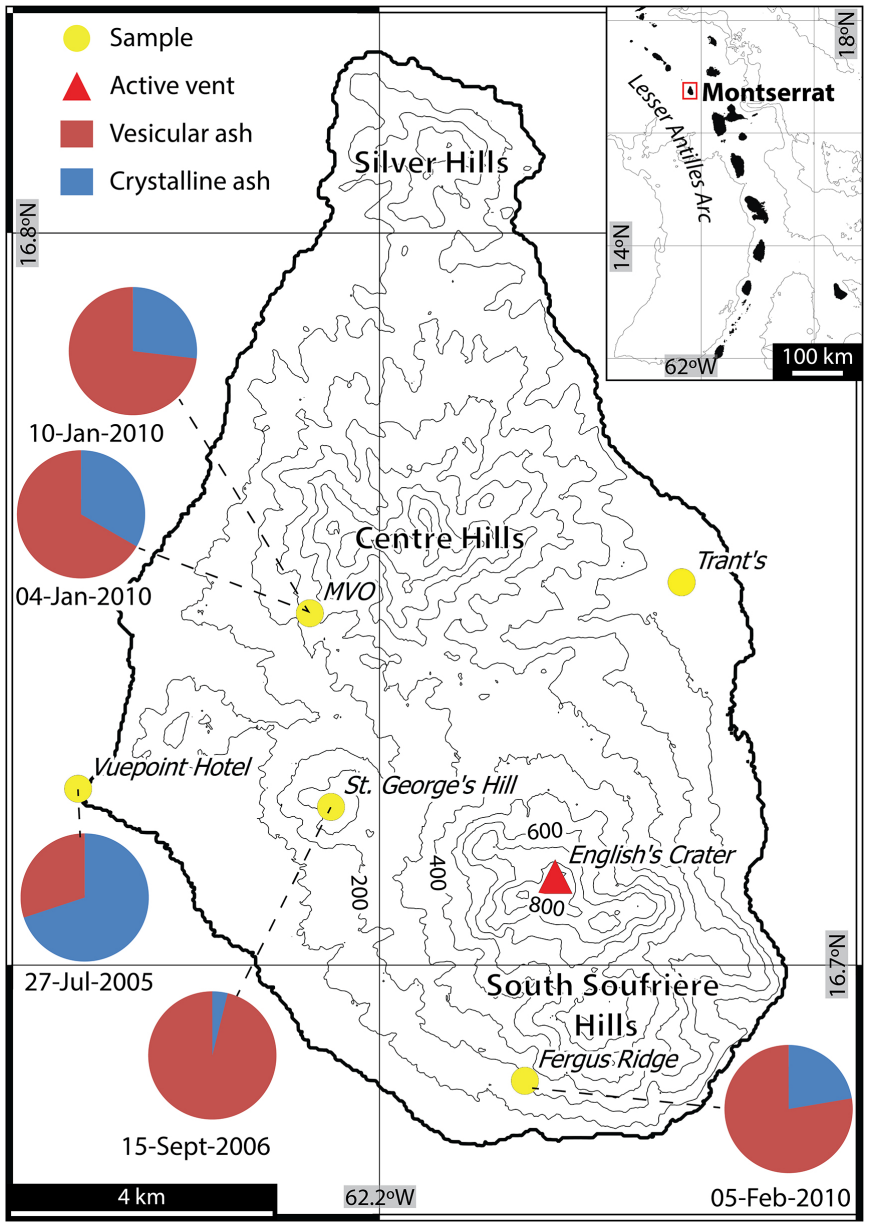




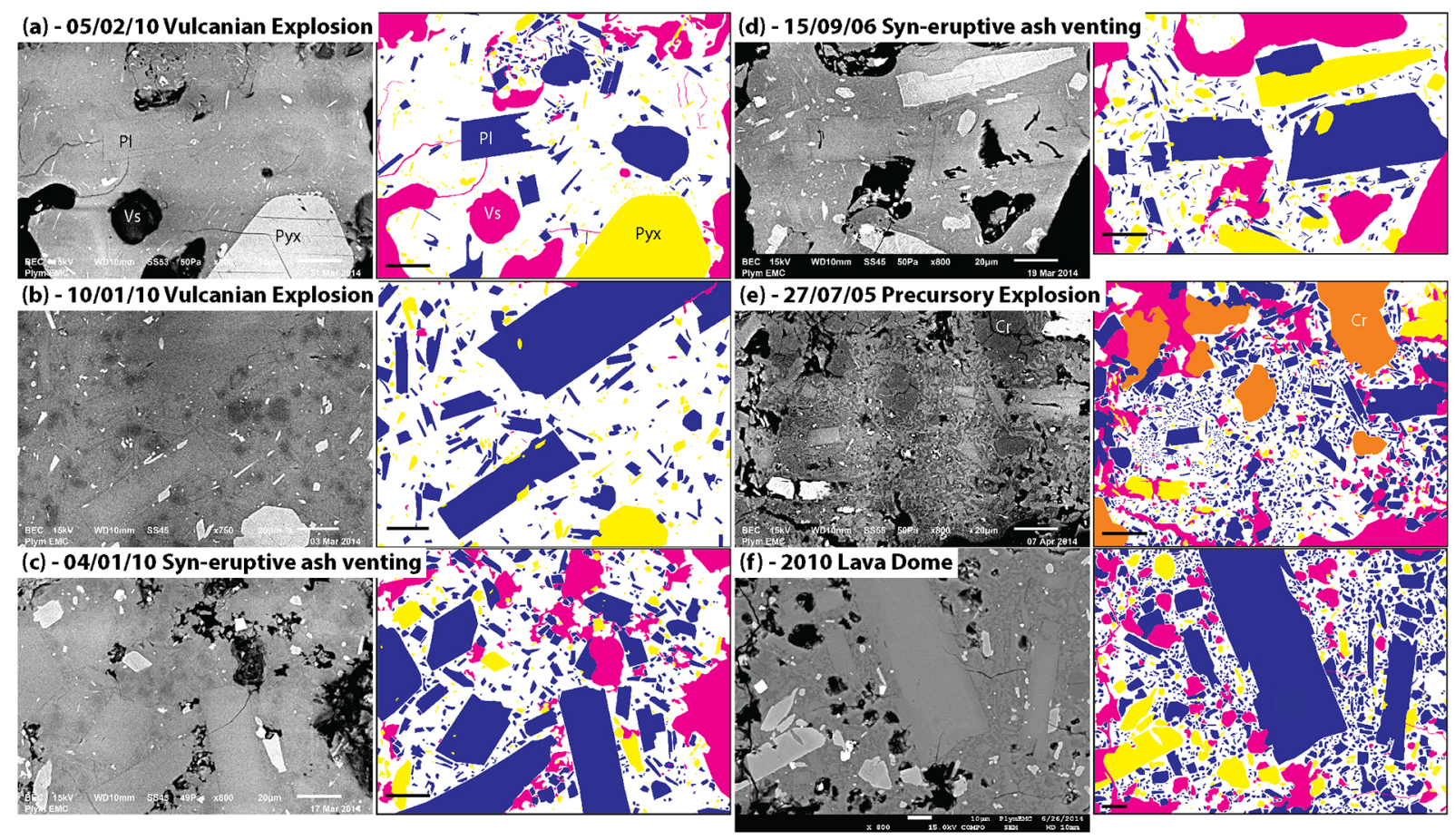

Figure 2 


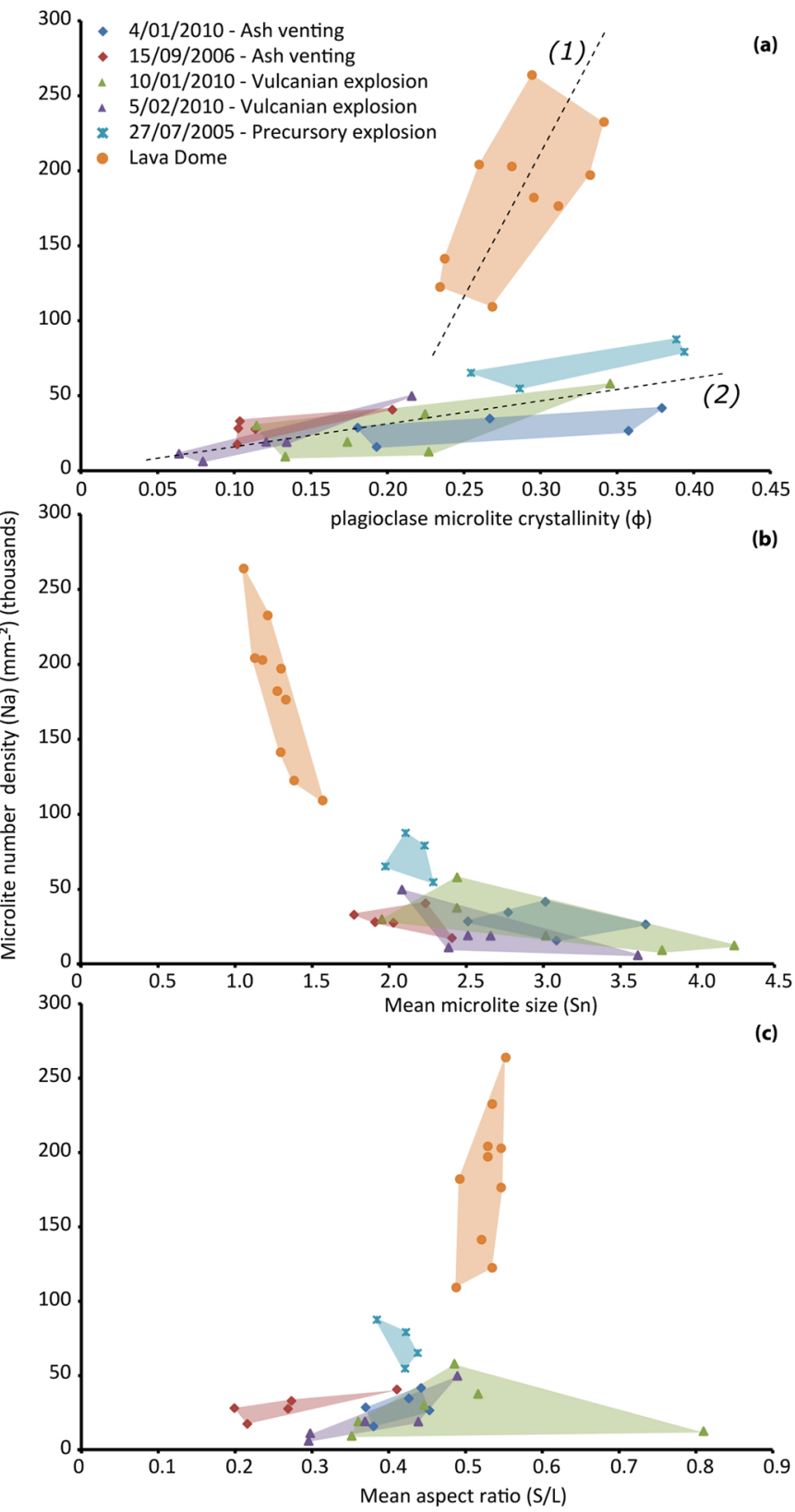

Figure 3 

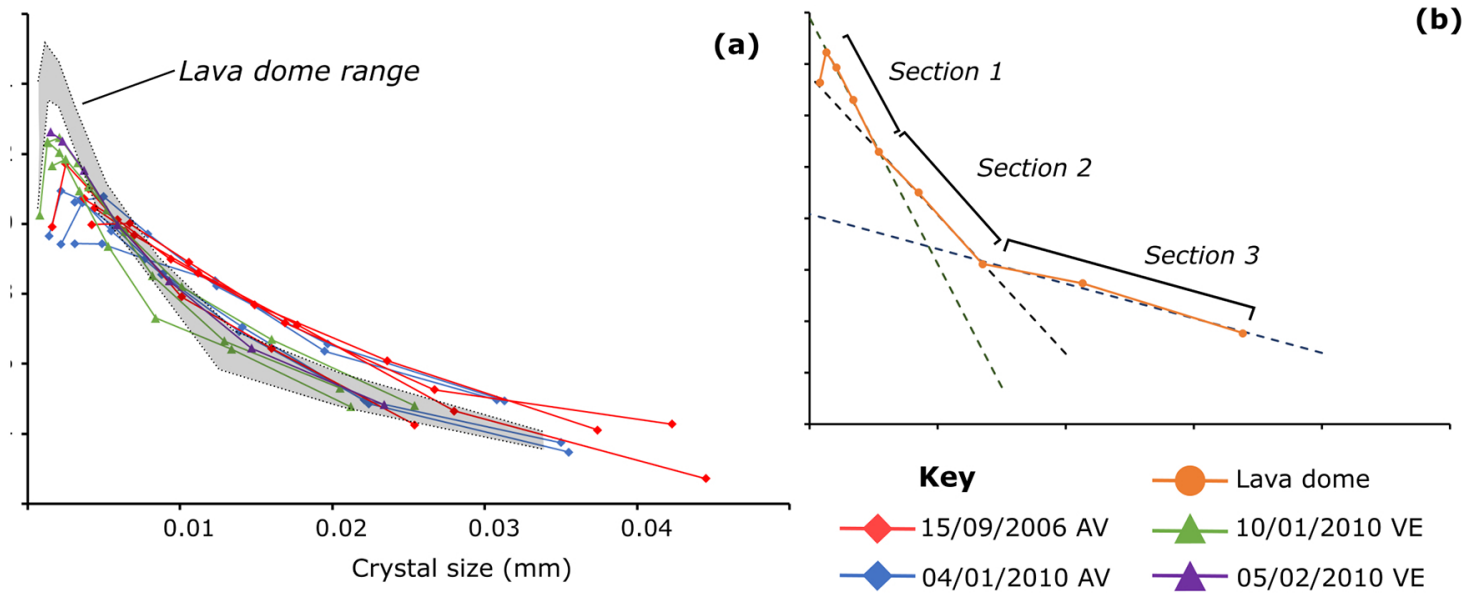

(b)
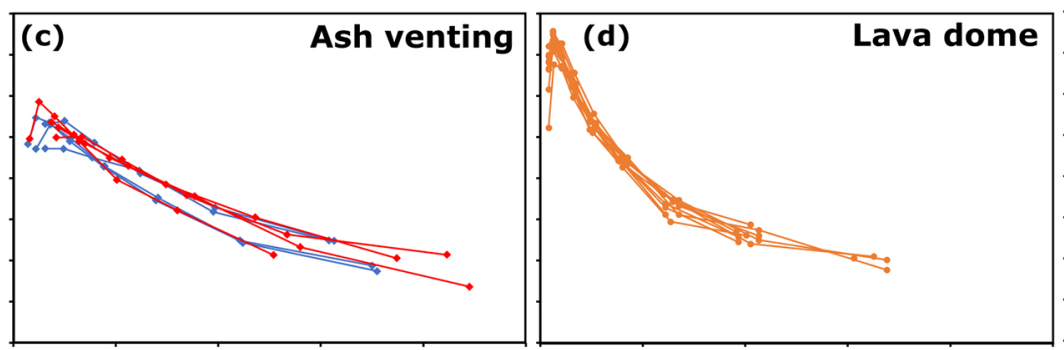

(f) 15/09/2006 Ash venting: S21_P6
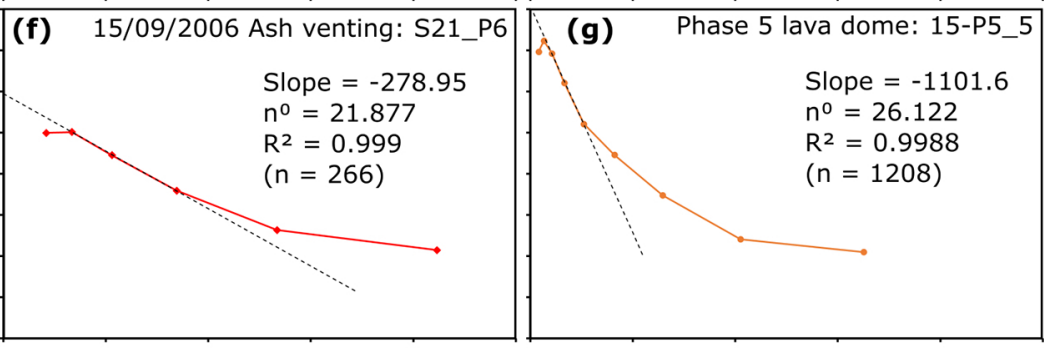

(i) 04/01/2010 Ash venting: S2_P12
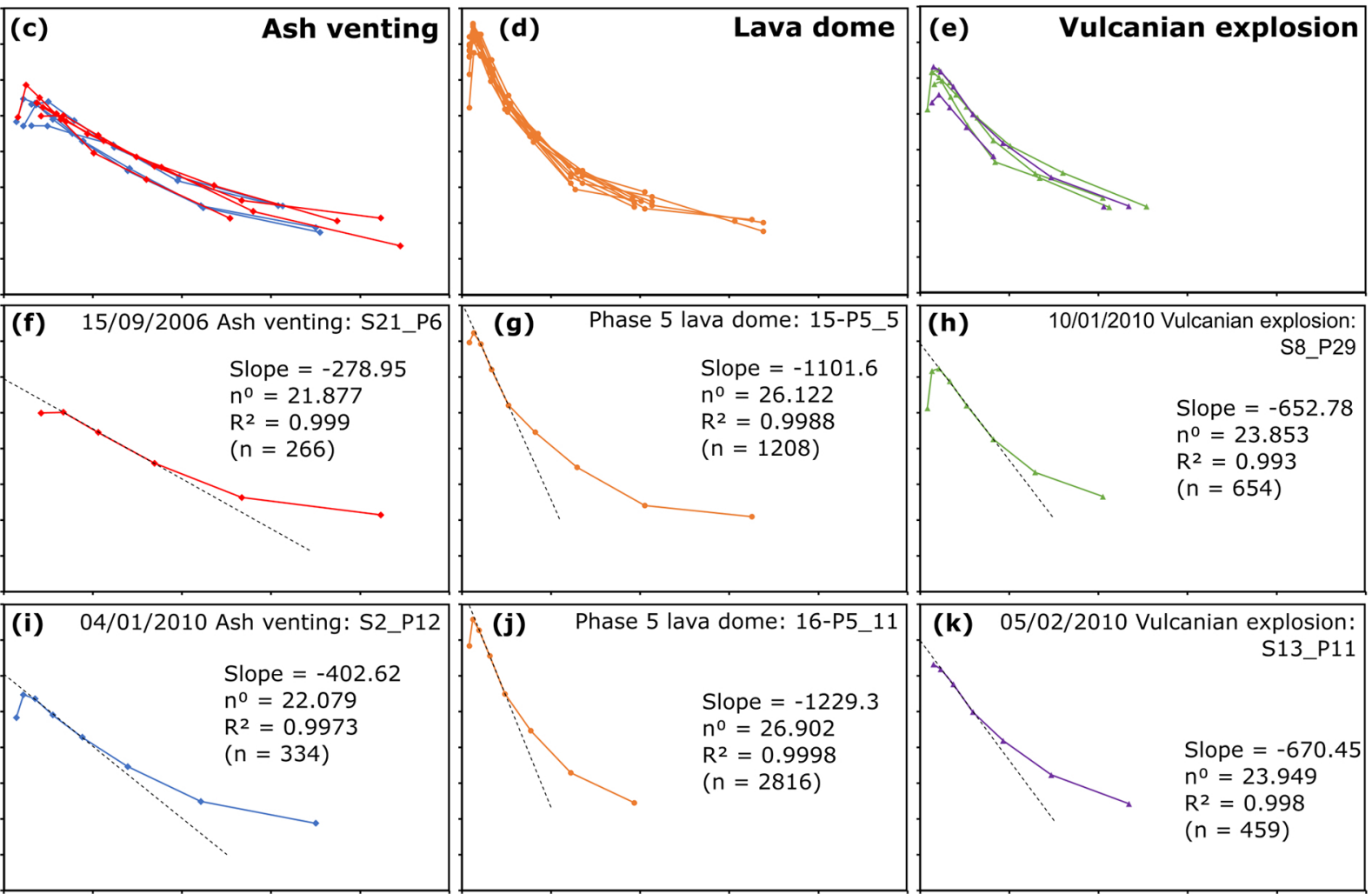

(k) $05 / 02 / 2010$ Vulcanian explosion: S13_P11

Figure 4 


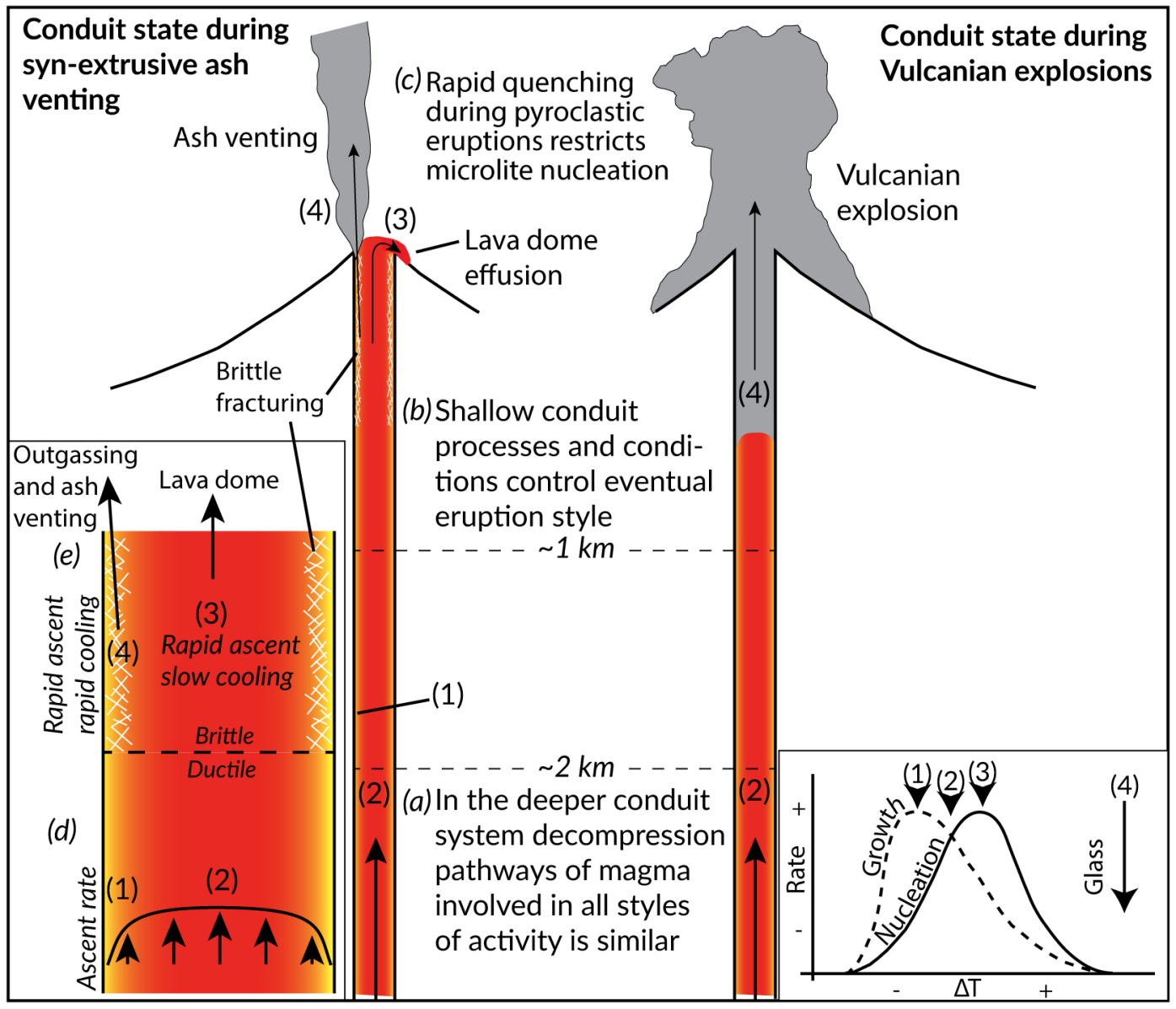

